\title{
COM \\ Online video on climate change: a comparison between television and web formats
}

\author{
Alicia De Lara, José Alberto García Avilés and Gema Revuelta
}

\begin{abstract}
This article proposes a classification of the current differences between online videos produced specifically for television and online videos produced for the Internet, based on online audiovisual production on climate change. The classification, which consists of 18 formats divided into two groups that allow comparisons to be made between television and web formats, was created through the quantitative and qualitative content analysis of a sample of 300 videos. The findings show that online video's capacity to generate visits is greater when it has been designed to be broadcast on the Internet than when produced for television.
\end{abstract}

Keywords

Environmental communication; Public perception of science and technology; Public understanding of science and technology; Science and media

Introduction: the growth of online video
Video is becoming a predominant component of Internet contents. By enabling users to produce, remix and share contents with a wide audience, the Web is an enormous audiovisual distribution channel, often with a viral impact [van Dijck, 2013, pp. 18-22]. The online video, in its broadest sense, consists of any audiovisual content format capable of being watched through the Internet. In general terms, it includes videos stored on YouTube, a la carte films and series, videos for mobile devices, video conferences, video blogs and a multitude of new formats [Burgess and Green, 2013]. The online video may also form part of more complex narrative units such as webdocs [Nash, 2012].

Online video consumption is one of the most popular Internet activities worldwide. According to industry data, online video penetration is near universal in most leading online markets and $25 \%$ of global Internet users consume online video every day [Statista, 2016]. Google sites, including YouTube, are currently attracting 160 million unique viewers per month and mobile video traffic is estimated to amount to 1.46 million per month [YouTube, 2016]. Video content accounted for $70 \%$ of the world's Internet traffic in 2014, and it will increase to $82 \%$ by 2020 [Cisco, 2016]. Television networks are still the primary producers of professional quality news videos and generate the majority of online news videos [Peer and Ksiazek, 2011]. In this way, traditional cultural industries expand their influence through social media to control the production and consumption of audiovisual contents [Benevenuto et al., 2009]. 
The online video brings together a large variety of components: moving images, still images, ambient sound, computer graphics, labelling, statements, music and inserts, with a hybridisation assimilated mainly by the young [Favero, 2014]. The narrative essentially has to be at the service of the information to be transmitted and has to encourage audience participation [García-Avilés, 2012; Burgess and Green, 2013], especially through users' comments and active debating [Thelwall, Sud and Vis, 2012]. Another key element is virality: a video becomes viral when a high level of reproductions is reached through being widely shared among users [Teixeira, 2012].

Web videos are often created by users. There is no commonly accepted definition of user-generated content (UGC). The Organisation for Economic Cooperation and Development (OECD) defines UGC as content made publicly available over the Internet, which reflects a "certain amount of creative effort", and which is "created outside of professional routines and practices" [Wunsch-Vincent and Vickery, 2007]. A third criterion allows UGC to be differentiated from professionally generated content (PGC), which is produced by the media and journalists. This distinction is becoming increasingly complicated as the level of quality of contents produced by amateurs means that on occasion it is difficult to differentiate it from professional content. It should also be borne in mind that the concept of "user" is complex since it includes not only the social function of the individual as a generator of participation and civil engagement but also their economic activity as a producer and distributor of contents [van Dijck, 2009]. As Kim [2012] points out, YouTube has a significant impact as a distributor of both UGC and PGC through its own commercial, advertising and legal system.

YouTube has become the preferred platform to watch videos due to its popularity and the fact that it is also free. Most of the videos on YouTube last no more than two minutes [Peer and Ksiazek, 2011]. Competition from other formats, the fight for audiences' attention and viewing on small screens encourages the production of brief online videos. Although they are not free of controversy in science, YouTube videos are a popular source to learn about science and technology, and are also increasingly cited by scientists in these fields [Kousha, Thelwall and Abdoli, 2012]. Thus, the potential of online video as a science communication tool is widely acknowledged, especially regarding the possibility of establishing a dialogue with the audience and building online communities [Erviti and Stengler, 2016].

Online videos are considered an accessible format in the dissemination of scientific information to a broader audience [Sugimoto and Thelwall, 2013]. They are not free of controversial aspects, especially concerning the limits of entertainment and amusement for explaining scientific contents [Pinto, Marçal and Vaz, 2015; Brewer and McKnight, 2015]. Moreover, online videos have been the object of research on the communication of risks in areas such as climatology, medicine and health, and there is increasing concern about the lack of rigour of such contents [Welbourne and Grant, 2015].

The mainstream media is the public's main source of environmental information [Allan, Adam and Carter, 2000, p. 200]. Numerous studies, including those focussed on the international media [Hansen, 1993The Mass Media and Environmental Issues; Boykoff, 2008] as well as the Spanish media [Meira et al., 2013; De Lara, 2014], have demonstrated that climate change does not receive the 
same attention as it does on television or in the press. Several factors, such as time, audience or budgetary constraints, make it difficult for broadcast media to cover climate change in greater depth. However, these limitations are not so prevalent on the Internet; here, the users are those who choose when they watch contents and how much time they dedicate to doing so.

With the aim of contributing to the study of online audiovisual production on climate change, this article proposes a classification of the differences between online videos produced for television and online videos produced specifically for the Internet.

Online video as a tool to communicate science
Entertainment media and social media influence the perceptions of science and research and represent growing channels for the popularisation of scientific culture [Allgaier, 2013]. In this respect, Tan, Jocz and Zhai [2015] found that popular culture and social media strongly influence and shape how children view scientists. Websites in general and online videos in particular may play an extremely important role in the so-called "informal education" processes [Jeffs and Smith, 1990, pp. 6-11] as well as enabling users to become active participants in relation to science without neglecting the importance of maintaining certain parameters of scientific rigour that ensure their quality [Van Riper, 2003]. The production of science videos and blogs provides opportunities for the public to participate in, and learn about, scientific processes [Brown Jarreau, 2015, p. 2] and generates greater possibilities of engaging with science issues [Roth and Friesen, 2014].

We understand the term online science video to refer to that format that shows on the Internet content about a science issue with an educational objective aimed at a wide audience. In science videos, the need has arisen to sacrifice a certain degree of the message's complexity and rigour in order to make the advances, problems and questions related to science more accessible to the public [Dunwoody, 2008, pp. 18-21]. Throughout this article, we will use the term "online science video" and "science video" interchangeably when referring to the definition described above. Similarly, our study differentiates two types of formats: on the one hand TV formats, i.e. those videos whose primary broadcast channel is television, and secondly, the Internet; and, on the other hand, web formats, which are those videos whose diffusion is limited to the Internet, since this is the medium for which they were originally created.

Online science videos are characterised by their diverse formats. On the one hand, there are formats typical of television journalism, such as news, reports and interviews. On the other, news contents are combined with other promotional, fictional or persuasive contents. The variety of producers, genres and formats makes it difficult to establish a classification, since not all producers are considered scientific communicators and the success in the distribution of contents and their rigour depend on different criteria, especially as a result of their popularisation on YouTube [Welbourne and Grant, 2015]. Therefore, it should be borne in mind that there are widely varying standards that depend on content quality, production values, the level of entertainment and scientific rigour.

The classification of videos into different types, therefore, becomes a complicated task as the numbers of videos created by users and their peculiarities increase 
exponentially [Geisler and Burns, 2007]. At the same time, some producers of scientific videos are not familiar with the standards of science nor are they subject to the supervision of scientific rigour [Kousha, Thelwall and Abdoli, 2012]. As highlighted by Muñoz Morcillo, Czurda and Robertson-von Trotha [2016, p. 7] in their study of science videos published on YouTube, "the results suggest that the most popular science videos are not always the most complex or in-depth". This same study provides a preliminary statistical analysis of the types and characteristics of the most popular science videos on YouTube and identifies a wide variety of genres and subgenres.

Our study analyses popular videos on climate change published on the Internet, with the aim of establishing a classification of the main current formats of online science videos. We chose videos about climate change as it is considered one of the most important topics in terms of scientific communication since 1988, when the Intergovernmental Panel on Climate Change (IPCC) was established and a severe heat wave notably increased the amount of information on this phenomenon [Greenberg et al., 1989]. And also because, in general terms, the media is the place for the privileged discussion to address environmental risks [Hulme, 2007, pp. 117-120].

Various studies have analysed the communication of risks associated with climate change [Smith, 2005; Painter, 2013], the public's perception of this problem [Lorenzoni and Pidgeon, 2006; Sterman, 2008; Morton et al., 2011] and the current controversy surrounding this environmental risk [León and Erviti, 2011; Lopera and Moreno, 2015]. The coverage of climate change has been addressed from the perspectives of scientists, journalists and the public [De Lara, 2014], and its framing on television news programmes tends to focus on negative issues and environmental threats [Hart and Feldman, 2014]. Moreover, the low level of coverage of climate change on television news may be related to the scarcity of attractive images available to TV channels [León and Erviti, 2015].

Objectives and research questions
The main objective of this study is to propose a classification that establishes the current differences between online videos produced for television and online videos produced specifically for the Internet, from a sample of 300 pieces that address the problem of climate change. The analysis centres on aspects relating to: the authorship of the videos, the specific terminology used to explain climate change, the main objectives of the videos or their capacity to generate interaction with users, among other aspects. The classification was built from the quantitative and qualitative study of the sample used. This investigation proposes a method that allows online videos about climate change to be classified in a technological and media context that is undergoing continual change and evolution, and in which online videos have gained notable importance as transmitters of knowledge.

Complementary to the main objective, this study also analyses the general characteristics of the sample. In other words, it studies aspects related not only to the channel for which the videos were originally created but also compares other aspects relating to authorship, themes, and even the length of the pieces. These aspects are analysed comparatively in both videos made for television and later transmitted on the Internet, and those designed specifically for the web. 
A content study was employed for the analysis and classification of the videos, and was used to analyse quantitative aspects such as duration and other aspects in addition to formal and technical ones. For example, those related to the content of the video itself (the video's objective or main theme) or rigour (the presence of specialised terminology). Recent studies use this method in the analysis of online videos similar to that proposed here [Kousha, Thelwall and Abdoli, 2012]. It should be pointed out that in the content analysis applied to this study and carried out over three months, from December 2015 to February 2016, a sample of 300 videos addressing the issue of climate change was processed. The questionnaire (see appendices) designed to carry out the analysis includes items that describe both formal/quantitative aspects and others that examine in detail the content of the video and the theme itself with the aim of analysing the sample beyond the formal point of view.

We opted for the Google video search engine because, being the widest tool employed by users, it would yield the videos with the greatest potential projection. For the search, carried out in October 16 2015, a window was opened in Google anonymously and the term "climate change" was introduced. All cookies were desactivated and the memory caches were cleaned, as these factors may interfere with the reliability of the results.

The sample has limitations that need to be taken into consideration. It cannot be considered representative of media consumption by the public in general. On the contrary, it represents a search in a country (Spain) at a specific moment (October 16 2015). Similarly, the sample is made up of videos that address the theme of climate change but not only from specialised sources. On the contrary, in addition to videos published by media that specialise in science, such as TED talks or the Science Museum website, it also includes videos from, for instance, The Guardian and Fox News in addition to videos published directly on YouTube, which make up a considerable number of those found in the search.

Of the 112 million references that appeared when the term "climate change" was entered into the search engine, Google only returned the 600 most relevant, which were conditioned by the search engine algorithm. Two coders then selected only those videos whose main theme was climate change. The exclusion criteria used were: links that did not lead to videos (31 items), videos that did not cover the subject matter as the main issue ( 83 items), links that contained the same video as a previous link (122 items) or that had any other type of problem that prevented the correct coding (16 items). Videos (48) that exceeded 20 minutes in length were also rejected due to limited resources; coding videos longer than 20 minutes requires an effort that lies beyond this current study. After cleaning up the results, the final sample was reduced to a total of 300 .

Before commencing coding, a pre-test of the questionnaire was carried out in which the two coders applied the code to $5 \%$ of the sample, with the aim of detecting problems of comprehension and carrying out appropriate adjustments. Following this testing phase, the conclusion was reached that it was necessary to explain that the videos ought to be classified according to their main objective, given that several different possible objectives were detected in some videos. In other words, it was specified that the coders should choose the clearest option of those proposed in the questionnaire. 
With regard to the section of the code that analyses video formats, it should be pointed out that the format is considered one of the essential pillars of the media production and publishing rationale [Soulages, 2007, p. 78]. Saló [2003, p. 13] believes that the concept of format refers to the formal and thematic aspects of a video and defines it as "the specific development of a series of audiovisual elements and contents that constitute a determined programme and differentiate it from others". For their part, Alvarado et al. [2014] point out that the capacity of a format can be limited and highlight that "a TV program format can thus be understood as the deliberate enhancement of the adaptability of a program. It is that complex and coherent body of knowledge assembled by an owner that permits and facilitates the imitation of a TV program by another".

The classification of formats proposed in the code has certain limitations, since it does not differentiate the videos exclusively according to their structure. Rather, it takes into account other aspects such as, for example, the theme or genre. It is, therefore, a proposal that could be improved in future studies so that there would be no overlap between concepts and that the video structure would be exclusively considered with the aim of achieving greater rigour.

Taking into account the aforementioned limitations, the code designed to analyse the sample videos differentiates between 18 format types classified into two groups:

\section{TV formats:}

TV Programme: factual or fictional television content (or a fragment thereof) that is broadcast on a channel or the Internet. In this study, this is applied to spaces that are not interviews, news items, documentaries or debates, for example a talk show.

TV News: a fragment of a television newscast or a complete news broadcast.

TV Feature / Documentary: a film or television programme (or a fragment thereof) presenting a political, social or historical subject in a factual and informative manner and often consisting of news clips or interviews accompanied by narration. It focuses on representing reality using all available techniques [Nichols, 1991].

TV Interview: a conversation between a journalist and an interviewee (or a fragment thereof).

TV Debate: a television format in which the debaters present their various points of view on an issue with the intervention of a presenter who allocates times and moderates the discussion [Livingstone and Lunt, 2002, pp. 36-40].

TV Conference, video recorded: a talk or complete lecture (or a fragment thereof) in which the speaker sets out his/her knowledge of a particular subject.

TV comedy video: a brief scene or sketch in which one or various people appear with the aim of entertaining [Krutnik and Neale, 2006, pp. 12-14].

TV Video analysis or Statements: fragment in which an individual's opinions or analysis are reproduced or may form part of a programme or news item. 


\section{Web formats:}

Web Interview: a complete interview or fragment thereof.

Video Blog: a series of videos published chronologically on a blog.

Web Documentary or webdoc: "interactive applications, on or off-line, made with the intention of representing reality with its own mechanisms that we can call modes of browsing or interactivity, relative to the level of participation allowed" [Gifreu, 2011].

TV Video analysis or Statements: fragment in which an individual's opinions or analysis are reproduced or may form part of a programme or news item.

Web Music video: a short film with a loosely connected flow of action around a theme, integrating a song and imagery, produced for promotional or artistic purposes [Aufderheide, 1986].

Web News: a complete television newscast or a fragment thereof.

Web Promotional video: content whose main aim is to promote a product or service in order to achieve objectives within a marketing strategy.

TV comedy video: a brief scene or sketch in which one or various people appear with the aim of entertaining [Krutnik and Neale, 2006, pp. 12-14].

TV Debate: a television format in which the debaters present their various points of view on an issue with the intervention of a presenter who allocates times and moderates the discussion [Livingstone and Lunt, 2002, pp. 36-40].

TV Conference, video recorded: a talk or complete lecture (or a fragment thereof) in which the speaker sets out his/her knowledge of a particular subject.

The analysis code also included the following categories:

- Video title.

- Video creators. We decided to divide these into the following areas: scientific institution; private company; television channel; other media outlets; scientific publication; non-scientific institution/association/NGO; individuals (user generated content); and others, which included both videos that fell outside the previous categories and those for which it was not possible to determine the category to which they belonged.

- Length.

- Main objective: six objectives were established: information; awareness-raising/persuasion; entertainment/infotainment; education/training; commercial; others.

- Video theme: scientific; political; economic or social; others (for example, commercial content).

- Presence of scientific terminology and an explanation of concepts.

- Inclusion or not in the video of components that encourage interaction. Interaction was considered "low" when the only call for action was 
"subscribe"1 and "medium" when, in addition to a subscribe button, links to other videos or other actions were also included (usually at the end). ${ }^{2}$ Lastly, interaction was considered "high" in the case of webdocs, where the involvement of viewers is extremely elevated. The sample included online documentaries but did not include any video with a webdoc-specific format.

- Number of views and comments, in those videos which showed this information. This parameter is measured as a way to test the ability of the video to invite to participation [Burgess and Green, 2013, p. 54]

Once the coding of the videos was completed, a reliability test was carried out. The test consisted of taking $10 \%$ of the coded sample, i.e. 30 videos, and comparing whether the coding carried out by the coders agreed. The agreements between the two coders that performed the task were higher than $85 \%$ for each variable. There were two variables in which reliability was less than $85 \%$, and were thus ruled out of the analysis. These excluded variables were: the video scenario and the dominant framework.

\section{Analysis of results}

\section{Classification of online science video formats}

Firstly, Figure 1 underlines the existence of a wide variety of formats already mentioned in previous studies. Therefore, the analysis of the sample enabled 18 formats of video to be distinguished, where it can also be observed that the proportion of each format differs notably depending on each case. Focusing on the five most frequently occurring formats, we see that the greatest percentage of online videos analysed are recorded video conferences (15.7\%). in second place, we find Internet-specific reports, which make up 15\%; in third place are the various video blog formats (10.7\%); in fourth, the web video of analysis and statements $(6 \%)$ and, in fifth place, interviews and reports produced for TV $(5.3 \%$ in both cases).

Having established a classification of the formats, we were able to confirm that they could be easily classified into two separate groups: a first group of formats for television news or production for television, and a second group of formats for the Internet itself. Table 1 shows the various formats in these two groups, established according to the original intended transmission.

Once regrouped, Figure 2 reveals that the highest percentage is made up of those videos in the Internet formats group, constituting $68 \%$ of the total, while the made-for-television formats accounted for $23.3 \%$. One the one hand, we have established a first group of videos in which the television provenance can be identified, for example, because they retain the channel's logo or because they are clips from programmes aired on television. We also differentiated a second group of videos: those videos designed specifically for the web. Nevertheless, mention

\footnotetext{
${ }^{1}$ An example of "low" interactivity was found in the case of science videos on the Prager University channel, in which, at the end of the video, viewers were invited to subscribe to the channel https://www.youtube.com/user/PragerUniversity.

${ }^{2}$ An example of "medium" interactivity is a video in which viewers were invited to check their knowledge of climate change through a test: https:/ / www3.epa.gov/climatechange/kids / expeditions/arctic/.
} 


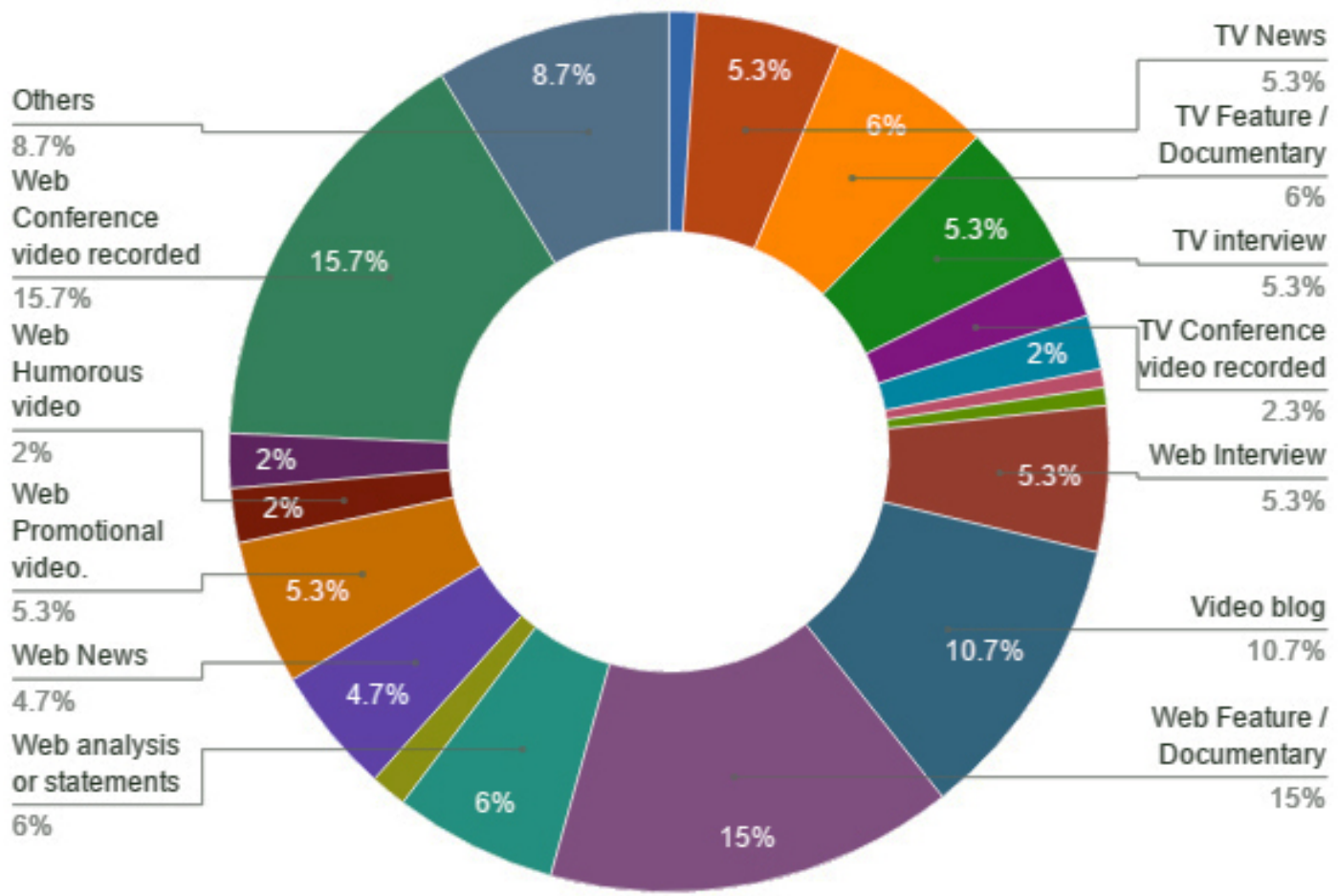

Source: Authors

Figure 1. Classification of online science video formats.

Table 1. Classification of the formats grouped according to the original intended destination.

\begin{tabular}{|l|l|}
\hline Television formats & TV Programme \\
\cline { 2 - 2 } & TV News \\
\cline { 2 - 2 } & TV Feature / Documentary \\
\cline { 2 - 2 } & TV Interview \\
\cline { 2 - 2 } & TV Conference video recorded \\
\cline { 2 - 2 } & TV Debate \\
\cline { 2 - 2 } & TV Comedy video \\
\cline { 2 - 2 } & TV Video analysis or Statements \\
\hline Web formats & Web Interview \\
\cline { 2 - 2 } & Video Blog \\
\cline { 2 - 2 } & Web Documentary or webdoc \\
\cline { 2 - 2 } & Web Analysis or statements \\
\cline { 2 - 2 } & Web Music video \\
\cline { 2 - 2 } & Web News \\
\cline { 2 - 2 } & Web Promotional video \\
\cline { 2 - 2 } & Web Comedy video \\
\cline { 2 - 2 } & Web Debate \\
\cline { 2 - 2 } & Web Conference video recorded \\
\hline Others & Other \\
\hline
\end{tabular}

Source: Authors 
should also be made of the possibility of establishing a third group of those videos whose original production was designed with the two formats in mind (TV and web), as in the case of videos created by news agencies that distribute them to their subscribers (television stations or digital media outlets). We have, however, ruled this group out but it is perhaps one that ought to be considered in future investigations.

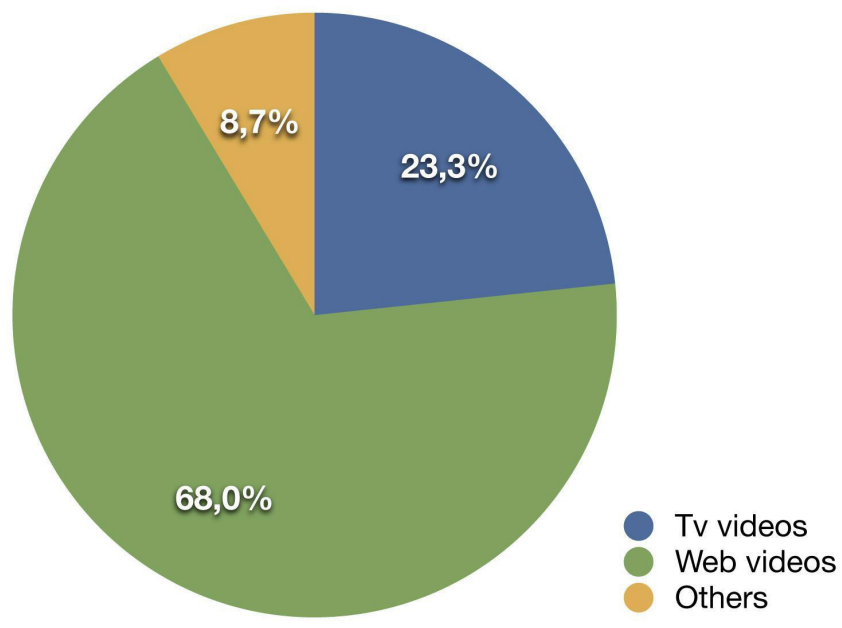

Source: Authors.

Figure 2. Percentage of videos grouped according to the original broadcast destination.

Next, it is worth considering whether the science videos not originally produced for an online channel achieved the same aims - for example, in terms of diffusion and virality - as those that were produced with the Internet characteristics in mind from the outset. Both aspects are analysed further on through a comparison of the comments and the total number of views obtained by the two different groups. These conclusions were reached after analysing first technical aspects, such as the length of the pieces, or characteristics related to qualitative aspects, such as the main objective of the videos and their creators, always under the subdivision of television formats and web formats.

\section{Producers of the videos}

From Figure 3, which shows the creators of the analysed videos according to the established classification, it is clear that science videos on climate change that were produced by general media outlets predominate. In this sector, which makes up $41 \%$ of the sample, we find large media outlets with an international perspective, including The Guardian, The Huffington Post and Associated Press, among others. For their part, television channels comprised $8 \%$ of the sample, with channels such as $B B C, C N N$ and Fox News. It also stands to reason that the television formats have a presence only in broadcasting companies and the media. In most cases, they are news format videos that cover political statements on the subject of climate change or videos from agencies that have supplied the information to the channel, which is also published on the channel's own website.

Figure 3 also highlights videos produced by scientific institutes — including NASA, the University of Sydney and the University of Wisconsin-Madison - 


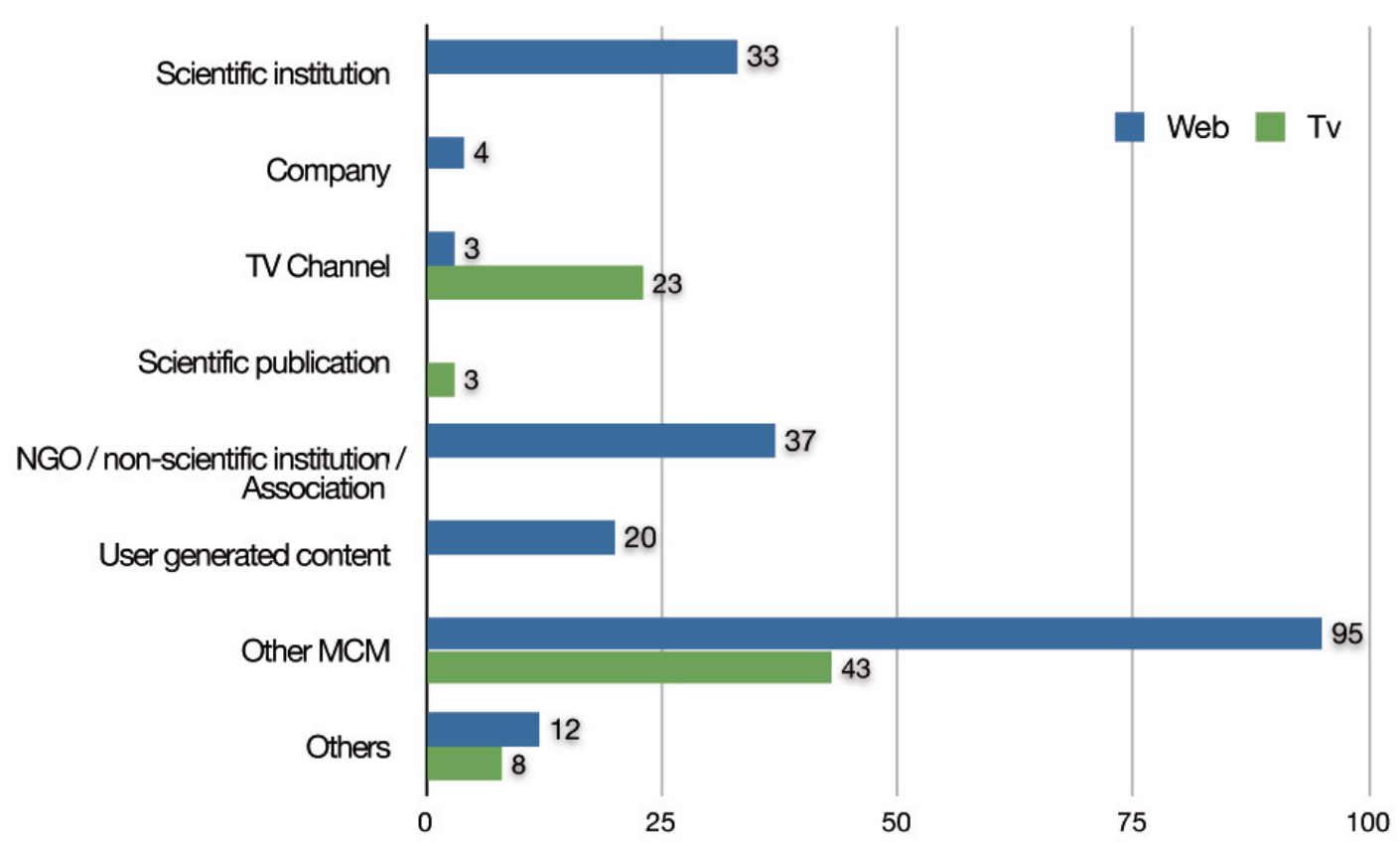

Source: Authors.

Figure 3. Producers of videos grouped according to the established classification.

which comprise $10 \%$ of the total and which are included within under Internet formats. Videos produced by non-governmental organisations are also worthy of mention. These make up $12.3 \%$. Within this group, we find entities such as the Science Museum and the World Wildlife Fund (WWF), which, unlike other producers, focus on creating videos specifically for the Internet. With regard to user-generated content, which represents just $6.6 \%$ of the total number of videos on climate change, videos of experts talking at conferences, video blogs and videos of statements are the most frequent.

\section{Length according to format}

In Figure 4, it can be clearly seen that videos on climate change available on Google are mainly pieces that vary between 1 and 3 minutes in length. Specifically, the largest block of videos is made up of those videos lasting between 1 and 2 minutes, followed by those that range between 3 and 6 minutes; from 6 minutes onwards, the number of videos decline, something which is seen in both the videos classified as television formats and web formats. In other words, there is a clear tendency for short videos: more than half the sample videos, $61 \%$, last $1-3$ minutes; $22 \%$ last between 3 and 6 minutes and the remaining $17 \%$ are longer than 6 minutes.

Moreover, it should be pointed out that videos longer than 10 minutes and closer to 20 minutes are mainly web-format conferences and discussions by experts.

Specifically, most of these recordings belong to TED, a not-for-profit organisation dedicated to the spreading of ideas through their webpage, generally in the form of conversations or talks. Other producers of longer pieces include universities and research centres, which also make their conferences and debates available to the public through their online channels. 


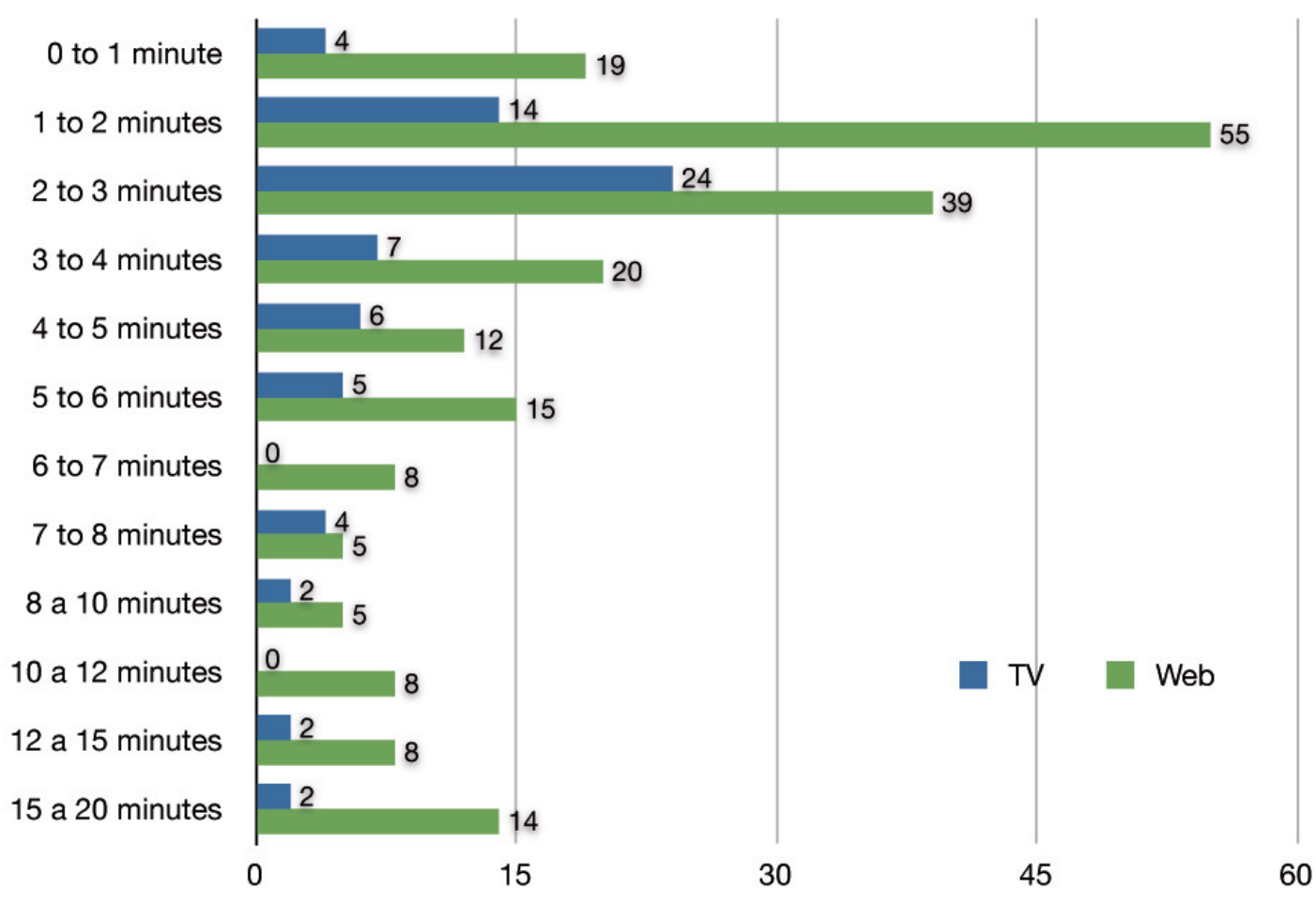

Source: Authors.

Figure 4. Length of video grouped according to the established classification.

There are no notable differences in the length of the videos when the established classification is taken into account, apart from those pieces making up the group of videos typical of television and the Internet that are between 1 and 3 minutes long, the standard length for online science videos. It is surprising that the web-format pieces are not limited to this segment corresponding to short videos, since the column representing web format videos is present throughout the chart and not only in the first positions. This leads us to think that, despite the fact that we have confirmed that the most frequent length of online videos is 1 to 3 minutes, the formats typical of online videos do not always share this tendency towards brevity.

\section{Objectives according to format}

The videos resulting from a Google search on the problem of climate change aim to be fundamentally informative and to raise awareness among the public, both in online and television formats. It should be considered a positive thing that these types of videos are treated from a responsible and respectful perspective in informative terms. Thus, as can be seen in Figure 5, 66\% (television format) and $40 \%$ (web format) of the sample videos have a principally informative objective, while 22\% (TV format) and 35\% (web format) aim to raise awareness. However, those with infotainment as their aim comprise $11 \%$ of the television format samples and $10 \%$ of those in web format.

A notable result is the extremely low percentage of videos with an educational aim, which aggregates only $3 \%$ of the web format videos, with no representation in television formats. Bearing in mind the specific characteristics of the environmental 
problem addressed and the need to raise awareness - something which is reflected in the awareness-raising percentage - it is surprising that the videos do not have an educational role on the subject matter. For example, there is a lack of videos that focus on the guidelines on specific action the public can take to combat the problem.

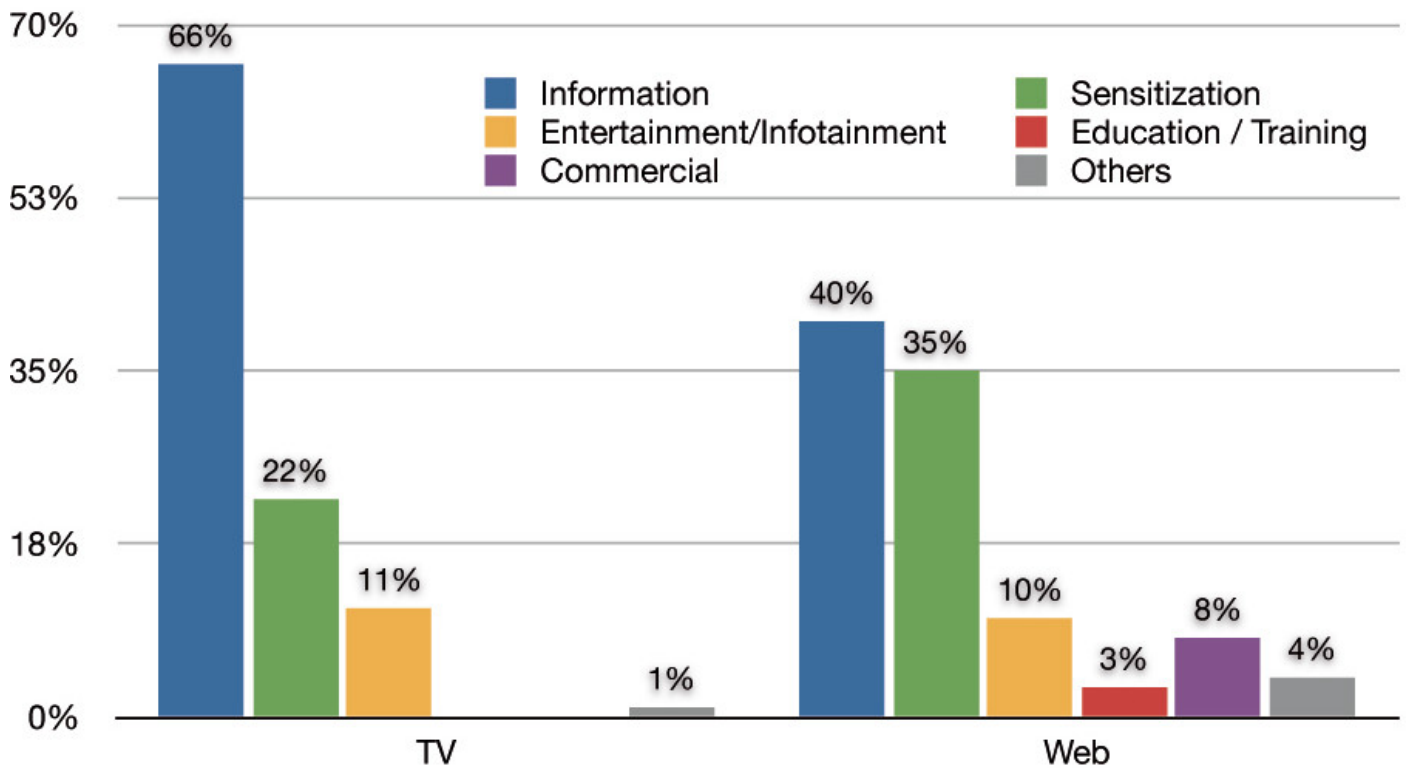

Source: Authors.

Figure 5. Objectives of the video.

With regard to the creators of the mainly informative videos, it should be pointed out that, predictably, the majority come from the media and television channels. On the other hand, the creators of videos with a mainly awareness-raising aim are, once again, firstly the media and secondly, associations, NGOs and non-scientific institutions. Finally, a commercial objective is only observed in online-format videos and represents $8.3 \%$ of the sample.

\section{The presence of scientific terminology}

Figure 6 analyses the presence of scientific terminology in the sample videos, a parameter directly related to scientific rigour. It is assumed that those videos that explain climate change in detail through the use of specific concepts are more rigorous. Similarly, it should be determined whether those videos that include scientific jargon make an effort to explain it and translate it so that it is easily understood by the viewer.

In general terms, we can see that the majority of the videos on climate change, including those published on the Internet, whether web formats $(89 \%)$ or television formats $(94 \%)$, do not include scientific terminology. Although the percentage of videos that use scientific jargon is greater for web formats than for television formats, the proportion in the former only reaches $11 \%$ of the total number of videos. Similarly, it should be pointed out that of the number of videos that do 


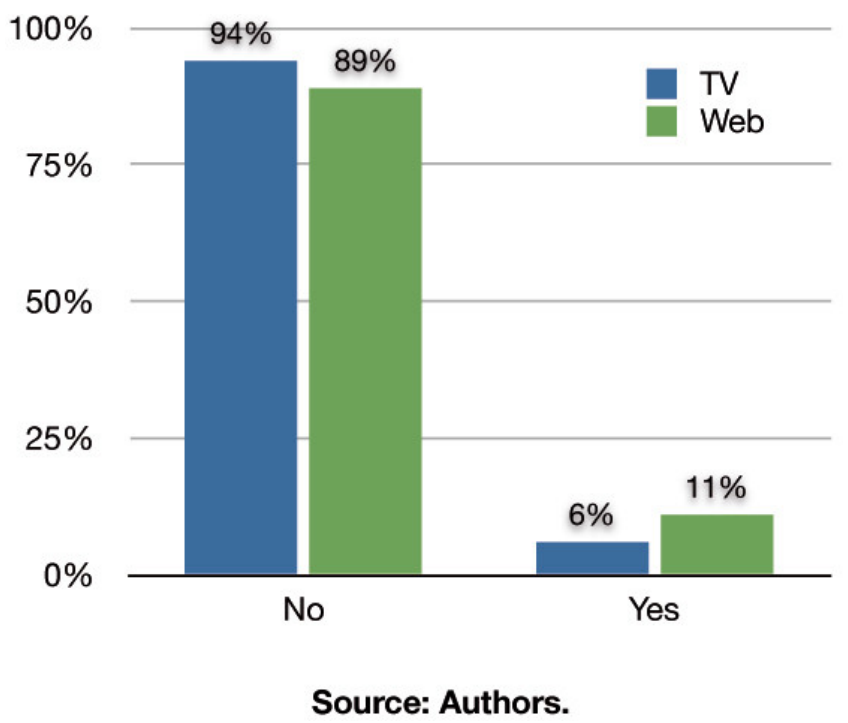

Figure 6. The presence of scientific terminology in the videos.

include scientific terminology, those that explain it do not reach $50 \%$, in neither web nor television format.

\section{Views, comments and elements that encourage interaction}

By analysing the total number of views of the various formats, we can confirm that those that have been designed to be shown on the Internet receive a much greater number of views than those produced for television. It should be pointed out that the count of comments and views has been restricted to those for which such data is available. In other words, we have been able to tally this data in all videos published on YouTube channels (which make up 23\% of the total) but not for those videos published by other websites in which this information is not shown. For this reason, Figures 7 and 8, which show the percentages of these parameters, are accompanied by tables showing the total number of videos of each format for which such information is available, along with the average.

Figure 7 shows that $80 \%$ of the views counted in the sample videos that provided this information are internet-format, while the remaining $19.5 \%$ of the total views correspond to television-format videos. We can confirm that web-format videos received an average of 526,379 views, while those designed for television received an average of 13,600 views.

The analysis of the comments received by the various science videos is decisive in demonstrating that Internet-format videos generate a greater response: The total number of comments registered by this subgroup exceeds 130,000, amply surpassing television-format videos (21,066 recorded comments).

Among the videos that generated the most comments, we find one, published by the channel Big Think, which shows a debate in which the science presenter Bill Nye participates in a discussion about climate change between politicians and scientists titled "You Can't Ignore Facts Forever". Among the more than 7,000 comments recorded by this video to date, there is a disperse dialogue that 


\begin{tabular}{|l|c|c|c|}
\hline & Total of videos & Total of views & Average \\
\hline TV & 17 & 231,205 & 13,600 \\
\hline Web & 70 & $36,846,561$ & 526,379 \\
\hline
\end{tabular}

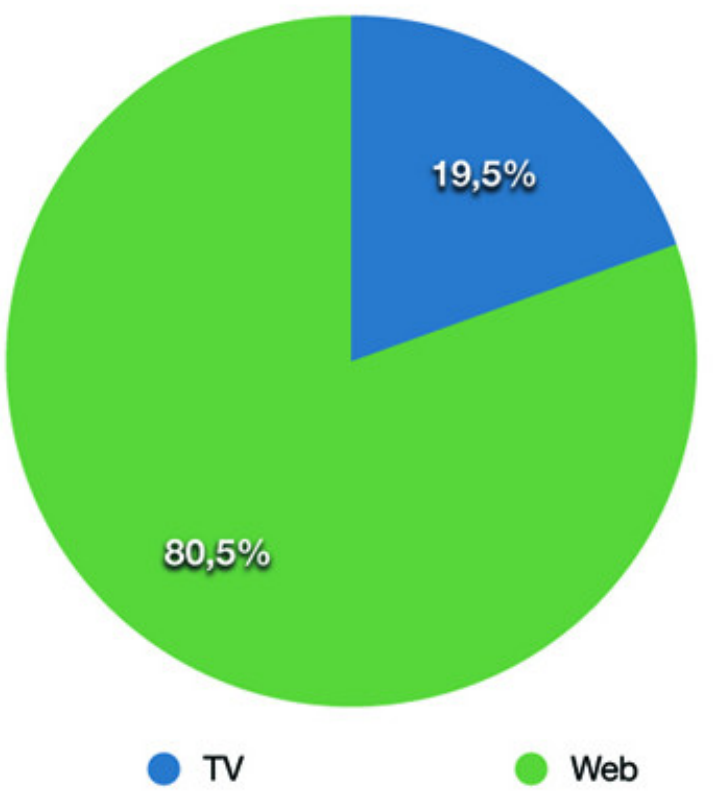

Source: Authors.

Figure 7. Number of views according to the established classification.

addresses many points of view on the subject. Another video that stands out for the number of comments generated, titled "Climate Science: What You Need To Know", which has generated over 3,000 comments to date. It was published by Joe Hanson on his YouTube channel "It's Okay To Be Smart". The comments focus on aspects relating to climate change prediction models or the melting of ice at the poles and, as with the previous example, some of the opinions contribute to the discussion constructively, while others are more superfluous and less edifying. The aims of this study do not cover the analysis of comments, which doubtlessly would yield interesting perspectives on the participation of users and would constitute a future line of investigation.

The analysis of the presence of elements that foster interaction was only carried out in videos designed for the Internet, since there are no such elements that allow for this in television-formatted videos. Figure 9 shows that not even web formats make the best use of the advantages of interactivity provided by the Internet. Only 14\% of the Internet-formatted videos provide some type of element that encourages interaction. Of this low percentage, $12 \%$ show a low level of interaction and $2 \%$, an average level. 


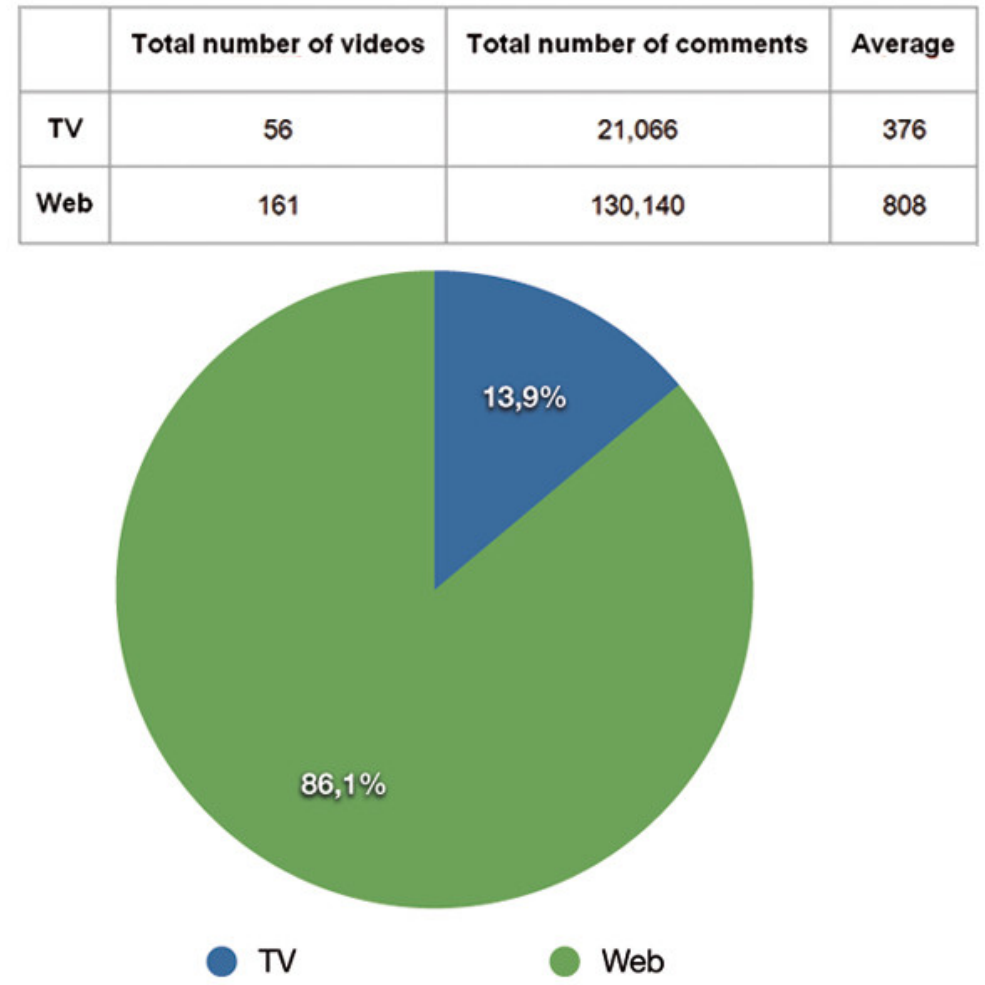

Source: Authors.

Figure 8. Number of comments according to the established classification.

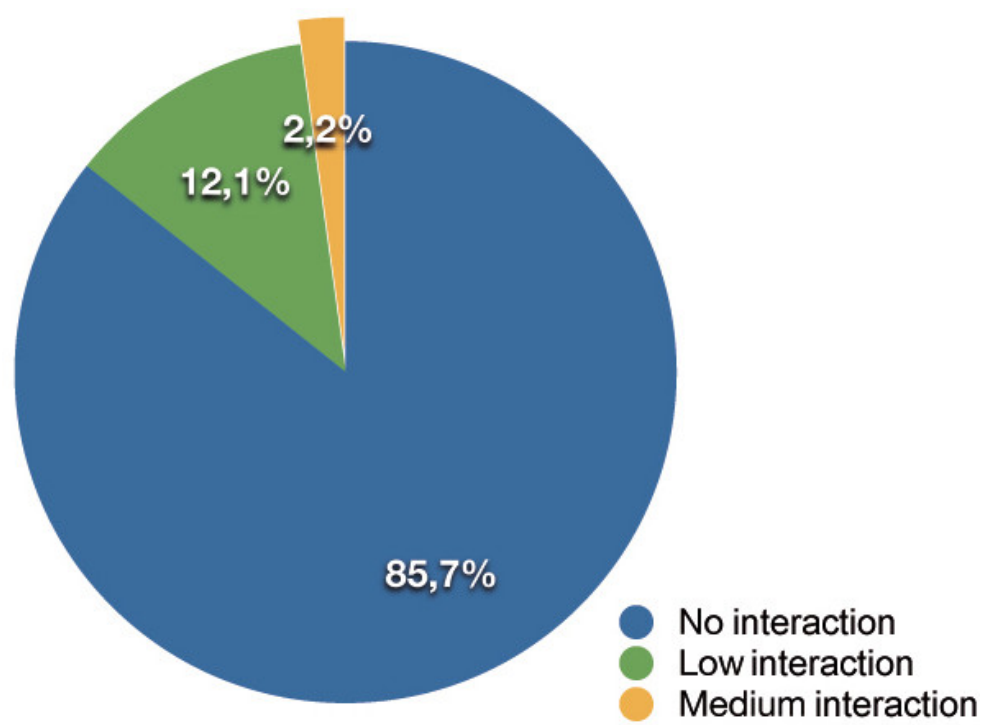

Source: Authors.

Figure 9. Presence of elements that foster interaction in web-formatted videos. 
The analysis of online videos on climate change provides us with a classification across 18 formats. In this way, our classification corroborates the conclusions reached in similar studies on the existence of a wide variety of genres and subgenres [Muñoz Morcillo, Czurda and Robertson-von Trotha, 2016; Burgess and Green, 2013]. These different formats have then been classified into two groups, according to the channel for which they were intended, with the aim of establishing their fundamental differences. These groups are: television formats and web formats. In other words, it can be seen that there are videos that have characteristics fundamental to television media formats (documentaries, news, TV interviews etc.) and that were initially broadcast by a television channel and later, or in parallel, published online. On the other hand, there are other formats exclusively produced for the Internet, including video blogs, conferences published by both scientific entities and individual users, or news videos published by media outlets on their websites.

Using this distinction (web formats and TV formats), the results demonstrate that the majority of videos on climate change published online are intended for the Internet. Similarly, the study shows that videos produced with the idiosyncrasies of the Internet in mind receive a greater number of views and comments, in comparison to those videos produced for broadcast on television and later published on the web. However, it is important to remember that on this point some of the videos do not show the total number of visits. As such, part of the sample cannot be taken into account in this regard.

The results also reveal that, despite the fact that the large majority of videos analysed are pieces produced specifically for the Internet, they do not take advantage of all the interactive potential provided by the web. In other words, when it comes to fostering audience participation, the Internet offers advantages that other channels do not have. However, if the capacities of the Internet are to be fully taken advantage of, the messages should be adapted to its requirements and include elements that foster interaction with the user; something that, as has been demonstrated in this study, does not occur in all cases. This result is in contrast with those of Muñoz Morcillo, Czurda and Robertson-von Trotha [2016], which revealed that most videos analysed in their sample include typical elements that foster community building and allow for their dissemination. We believe that the differences in the results are due to the difference between the two samples.

With regard to the more general aspects of the videos, the audiovisual narrative accompanying online videos on climate change is composed of shorter pieces, a result which tallies with the conclusions reached by Muñoz Morcillo, Czurda and Robertson-von Trotha [2016]. Moreover, the main objectives of online videos on climate change are to inform and raise awareness. The educational aspect, in contrast to what might be expected and bearing in mind the specific characteristics of the subject of climate change, has no weight in the overall objectives. There is a lack of videos with guidelines on what the public can do or containing specific actions they can take to combat the problem or in order not to exacerbate it. Likewise, the analysis of the presence of scientific terminology in the videos reveals the lack of depth when explaining the content in the majority of cases. This result demonstrates, in turn, the scarcity of scientific rigour, since in addition to the fact that videos that include scientific terms are in the minority, only half of these make any effort to explain these concepts. 
In summary, the results demonstrate that the capacity of online videos on climate change to generate visits and foster audience participation is greater when the online video has been specifically designed to be transmitted on the Internet, rather than when it has been produced to be broadcast on television and is later published on the internet. Nevertheless, we have also observed that the full potential of the online video format is not harnessed, as the majority of such videos do not include elements that foster user interaction and that might thus increase dissemination. However, with all of the above one must consider the idiosyncrasies and the heterogeneity of our sample, which includes videos from media organisations and organisations specialized in scientific dissemination, as well as others published by general media or directly on YouTube. Therefore, and in spite of the limitations referred to throughout the article, the study seeks to expand our understanding of the use of online videos as a tool to address the issue of climate change and places the focus on aspects that might contribute to a the better production and dissemination thereof.

Future lines of research should focus on widening the sample to other scientific issues of interest to confirm the validity of the classification established in this study. A further future line of research based on the study of reception might consist of creating an "intelligibility index", which would be created by asking test participants with little knowledge of climate change to rank the comprehensibility of the videos on the scale we propose. The classification of videos into different types will also continue to be analysed with the aim of determining the characteristics of online videos that make them more effective in terms of science communication, taking into account, for example, the inclusion of specific technical elements characteristic of the Internet format. Innovation (CSO2013-45301-P). 
Appendix 1.

Questionnaire

(Version 19/04/2016)

The final version of the questionnaire is included in order to highlight those questions that did not offer sufficient reliability (in red) and those that were excluded from subsequent analysis.

Name and surname(s) of coder:

Date coding was carried out:

\section{Number}
1A. Video title
1B. Linked page

\section{Video author name}

2A. Author

1. Unknown

2. Science institute (research/technology centre/ university, etc.)

3. Company

4. Television

5. Other media sources (newspapers, radios, digital media outlets) etc.)

6. Scientific publication (e.g. Nature, National Geographic)

7. Association/ NGO/ Non-scientific institution

8. User-generated content (UGC)

9. Other. Please specify

3. Duration (in minutes, no greater than $20^{\prime}$ ). E.g. $0.40 ; 7.20 \ldots$

4. Video scenario (from local to global)

1. Undefined

2. Local

3. Regional

4. National

5. Continental. Please specify

6. Global

\section{Format type of online science video}

1. TV programme

2. News (TV or web)

3. Conventional TV report/documentary

4. Internet video report/documentary

5. TV interview

6. Video interview

7. Video blog experiment

8. Video blog monologue

9. Video blog/Exclusively infographic/animated video

10. Other type of video blog

11. Video analysis or statements

12. Promotional video

13. Music video clip

14. Video-recorded conference

15. Video debate

16. Video poster

17. Humorous video

18. Other 
6. For the videos that provide this information

6A. Number of views

6B. Possibility of sharing

6C. Possibility of choosing "Like" or "dislike"

6E. Number of comments

\section{Main objective}

1. Not clear

2. Information

3. Awareness raising/persuasion

4. Entertainment (with no or very little scientific information about the issue)

5. Infotainment

6. Education/Training (only videos associated with training courses, formal or not. For example, Prager University videos are considered educational, while TED talks are not)

7. Commercial (marketing communication, product sales and services, publishing of image of companies or institutions)

8. Other

\section{The theme framework of the video is mainly}

1. Cannot be identified

2. Scientific

3. Technological

4. Economic

5. Political

6. Social

7. Other

9. The main frame presents a

1. Benefit (possible benefits of adaptation and mitigation measures are highlighted)

2. Loss (potential negative consequences are highlighted)

3. Both

10. Is any scientific jargon used? Jargon is understood to mean, "specialised language used among scientists of a particular discipline and may be difficult for the public in general to understand".

1. No

2. Yes

Please specify $n^{\circ}$ of terms

11. Are scientific terms explained?

1. No

2. Yes

12. Are scientific concepts explained?

1. No

2. Yes 
Appendix 2. List of sample videos
Title

1 Climate Change - The University of Melbourne I Coursera

2 Climate Change: The State of the Science - YouTube

3 What They Haven't Told You about Climate Change

4 Climate Change in Four Dimensions - University of Melbourne I Coursera

5 James Hansen: Why I must speak out about climate change

6 Nasa: sea levels rising as a result of human-caused climate change

7 Our Future I Narrated by Morgan Freeman

8 Gar Gavin Schmidt: The emergent patterns of climate change

9 Climate Change 2014: Impacts, Adaptation, and Vulnerability

10 Climate Change - YouTube

11 Do you have to be a vegan to help fix climate change? video

12 A Way Forward: Facing Climate Change

13 Climate Change Denier News I satire - video - The Guardian

14 Climate Change - University of Exeter - FutureLearn

15 Climate change: Seven indisputable facts I TheHill

16 South Carolina floods: climate change intensified conditions, scientists say

17 UW Climate Change Video Contest - University of Washington

18 Climate Change 101 With Bill Nye the Science Guy

19 Senate votes that climate change is real I TheHill

20 Florida Officials Were Barred From Using The Term 'Climate Change'

21 'Last Ditch' Remedies for Climate Change - Bloomberg

22 Republicans' leading climate denier tells the pope to butt out of climate debate

23 Pope to Congress: Time to act on climate change, poverty

24 Climate change deniers are conspiracy theorists and are damaging the public debate on global warming, study claims

25 English - Climate Change 2014: Mitigation of ... - YouTube

26 NASA Climate Change - YouTube

27

What YOU Can Do About Climate Change - YouTube

28

The reality of climate change I David Puttnam I TEDxDublin The Next Frontier of Climate Change DC I The New Republic Obama: Climate Change 'Defining Threat of This Century'

31 Leonardo DiCaprio at the UN: 'Climate change is not hysteria - it's a fact ${ }^{\prime}$

32 The Smithsonian Institution Announces an Official Climate Change

33 Fishing on Lake Michigan in the Era of Climate Change

34 Climate Change: Economics and Governance

35 Pathways to climate change adaptation: the case of Small Island Developing States

36 Thousands March for Climate Change Before United Nations Summi
Linked page

University of Melbourne

International Geosphere-

Biosphere Programme

Prager University

UC San Diego

TED

The Guardian

Naciones Unidas

TED

IPCC

SciShow

The Guardian

National Geographic

The Guardian

University of Exeter

The Hill

The Guardian

Michael Moynihan y Sarra

Tekola

The Climate Reality Project

The Hill

Huff Post

Bloomberg

Climate Desk

CNBC

World Meteorological Organization

IPCC

Nasa

Pacific Institute for Climate

Solutions

TEDx

New Republic

Pamela Dockins para Voice of

America

The Guardian

Smithsonian Institution

Jashno B. Khl (Mako Films)

The London School of Eco-

nomics and Political Science

(LSE)

Université de Gèneve

NBC News

Continued on the next page 


\begin{tabular}{|c|c|c|}
\hline & Title & Linked page \\
\hline 37 & $\begin{array}{l}\text { Climate Change Policy and Public Health - University of Mel- } \\
\text { bourn }\end{array}$ & $\begin{array}{l}\text { University of Wisconsin- } \\
\text { Madison }\end{array}$ \\
\hline 38 & Teachers TV- Climate Change - The Causes - YouTube & Teachers TV \\
\hline 39 & Bernie Sanders Kicks Jim Inhofe's Ass Over Climate Change & Bernie Sanders Classics \\
\hline 40 & Climate Change is Boring - YouTube & Veritasium \\
\hline 41 & $\begin{array}{l}\text { Arctic Sea Ice I Expedition I A Student's Guide to Global Cli- } \\
\text { mate Change }\end{array}$ & $\begin{array}{l}\text { United States Environmental } \\
\text { Protection Agency }\end{array}$ \\
\hline 42 & $\begin{array}{l}\text { Al Gore criticizes Obama on climate change and 'insane' Arc- } \\
\text { tic drilling }\end{array}$ & The Guardian \\
\hline 43 & WEATHER VERSUS CLIMATE CHANGE & National Geographic \\
\hline 44 & $\begin{array}{l}\text { Climate Change Is Already Here, Says Massive Government } \\
\text { Report }\end{array}$ & Huff Post Live \\
\hline 45 & Obama to unveil tougher climate change plan I Reuters & $\begin{array}{l}\text { Reuters (con imágenes de } \\
\text { WhiteHouse.org) }\end{array}$ \\
\hline 46 & $\begin{array}{l}\text { Senior Cardinal Questions Pope's Authority on Climate } \\
\text { Change }\end{array}$ & DailyMail.com \\
\hline 47 & $\begin{array}{l}\text { Climate change is simple: David Roberts at TEDxTheEver- } \\
\text { greenStateCollege }\end{array}$ & TEDx \\
\hline 48 & Bill Nye to Climate Change Deniers: You Can't Ignore Facts & Big Think \\
\hline 49 & $\begin{array}{l}\text { Peter Dutton Is Very Sorry For “Lame" Climate Change Joke } \\
\text { Caught On Microphone }\end{array}$ & ABC News \\
\hline 50 & $\begin{array}{l}\text { Global Warming: The Science and Modeling of Climate } \\
\text { Change }\end{array}$ & University of Chicago \\
\hline 51 & $\begin{array}{l}\text { Barack Obama turns tables in David Attenborough climate } \\
\text { change interview }\end{array}$ & BBC \\
\hline 52 & Time to Act: climate change protesters march in London & The Guardian \\
\hline 53 & $\begin{array}{l}\text { Alice Bows-Larkin: Climate change is happening. Here's } \\
\text { how we adapt }\end{array}$ & TED \\
\hline 54 & Senate to vote on whether climate change is happening & The Hill \\
\hline 55 & Sea Level & $\begin{array}{l}\text { United States Environmental } \\
\text { Protection Agency }\end{array}$ \\
\hline 56 & Obama: No Greater Threat Than Climate Change - Sky News & Sky News \\
\hline 57 & Evidence of Gov. Rick Scott's ban on "climate change" & The Florida Channel \\
\hline 58 & $\begin{array}{l}\text { Climate Change Debate: Last Week Tonight with John Oliver } \\
\text { (HBO) }\end{array}$ & Last Week Tonight (HBO) \\
\hline 59 & Climate Change: Have We Reached the Point of No Return? & The Real News \\
\hline 60 & $\begin{array}{l}\text { Barack Obama: climate deniers pose serious threat to US se- } \\
\text { curity }\end{array}$ & The Guardian \\
\hline 61 & $\begin{array}{l}\text { Lindsey Graham Has An Entirely Reasonable Position On } \\
\text { Climate Change, Sometimes }\end{array}$ & Huff Post \\
\hline 62 & $\begin{array}{l}\text { Barack Obama in Alaska: global fight against climate change } \\
\text { starts here }\end{array}$ & The Guardian \\
\hline 63 & Brewery Climate Declaration - Ceres & The Denver Channel \\
\hline 64 & Climate Science: What You Need To Know - YouTube & $\begin{array}{l}\text { Joe Hanson, Ph.D.- It's Okay } \\
\text { To Be Smart }\end{array}$ \\
\hline 65 & GoPro: Climate Change and the Optimistic Future - YouTube & $\begin{array}{l}\text { Professor Richard Muller - } \\
\text { Berkeley Earth Foundation }\end{array}$ \\
\hline 66 & $\begin{array}{l}\text { Carly Fiorina makes mincemeat of interviewer Katie Couric - } \\
\text { Climate change }\end{array}$ & Yahoo! News \\
\hline 67 & $\begin{array}{l}\text { Our Changing Climate: Past, Present and Future - Future- } \\
\text { Learn }\end{array}$ & University of Reading \\
\hline 68 & $\begin{array}{l}\text { The pottiest and costliest mistake of our times: Forget his } \\
\text { tax and spend plans. Red Ed's climate change law in the } \\
\text { Brown years will cost } £ 50,000 \text { per home, says CHRISTOPHER } \\
\text { BOOKER }\end{array}$ & Mail Online \\
\hline
\end{tabular}

Continued on the next page 


\begin{tabular}{|c|c|c|}
\hline & Title & Linked page \\
\hline 69 & $\begin{array}{l}\text { Want to See Climate Change? Come With Me to the Mont } \\
\text { Blanc Glacier }\end{array}$ & Bloomberg \\
\hline 70 & Causes of Climate Change - University of Bergen & University of Bergen \\
\hline 71 & Emma Thompson: climate change deniers are 'bonkers' & The Guardian \\
\hline 72 & $\begin{array}{l}\text { How Will Climate Change Transform U.S. Cities? - The At- } \\
\text { lantic }\end{array}$ & The Atlantic \\
\hline 73 & the newsroom s03e03 climate change interview - YouTube & $\begin{array}{l}\text { Serie 'The Newsroom' (S03 } \\
\text { E03) }\end{array}$ \\
\hline 74 & $\begin{array}{l}\text { Where's the global warming?' Expert says public are growing } \\
\text { sceptical of climate change }\end{array}$ & Express \\
\hline 75 & What do mermaids think of climate change? & The Guardian \\
\hline 76 & $\begin{array}{l}\text { David Keith: A critical look at geoengineering against climate } \\
\text { change }\end{array}$ & TED \\
\hline 77 & Vicki Arroyo: Let's prepare for our new climate I TED Talk & TED \\
\hline 78 & $\begin{array}{l}\text { Neil deGrasse Tyson's 'Cosmos' Takes Down Climate Change } \\
\text { Deniers }\end{array}$ & MSNBC \\
\hline 79 & America's first climate refugees & The Guardian \\
\hline 80 & $\begin{array}{l}\text { Sea levels may rise by } 10 \text { FEET in the next } 50 \text { years: Climate } \\
\text { change targets could still lead to 'highly dangerous' global } \\
\text { warming, warn scientists }\end{array}$ & Mail Online \\
\hline 81 & ISIS Vs Climate Change - Which Kills More? Russell Brand & Russell Brand - The Trews \\
\hline 82 & Climate Change Denial Disorder - YouTube & Funny or Die \\
\hline 83 & Scientists: Climate change is happening - CNN Video & CNN \\
\hline 84 & $\begin{array}{l}\text { Pharrell Williams: climate change is defining issue of our } \\
\text { time }\end{array}$ & The Guardian \\
\hline 85 & Could natural factors be causing climate change? & Science Museum \\
\hline 86 & $\begin{array}{l}\text { Lord Nicholas Stern: The state of the climate - and what we } \\
\text { might do about it }\end{array}$ & TED \\
\hline 87 & Why People Don't Believe In Climate Science - YouTube & $\begin{array}{l}\text { Joe Hanson, Ph.D.- It's Okay } \\
\text { To Be Smart }\end{array}$ \\
\hline 88 & Climate Change Animation Shows Devastating Effects & $\mathrm{AJ}+$ \\
\hline 89 & Our climate models are WRONG, claims study - Daily Mail & $\begin{array}{l}\text { World Meteorological Organ- } \\
\text { ization }\end{array}$ \\
\hline 90 & How Climate Change Deniers Sound to Normal People & Girl Pants Productions \\
\hline 91 & $\begin{array}{l}\text { Dear Bill Gates: 'Will you lead the fight against climate } \\
\text { change?' }\end{array}$ & The Guardian \\
\hline 92 & $\begin{array}{l}\text { Pope Scolds World Leaders on Global Economy, Climate } \\
\text { Change }\end{array}$ & Bloomberg \\
\hline 93 & $\begin{array}{l}\text { Could an ASTEROID protect Earth against climate change? } \\
\text { Teenager proposes how to create a dust screen using orbiting } \\
\text { rocks }\end{array}$ & Danila Kuznetsov \\
\hline 94 & $\begin{array}{l}\text { Climate Change Is Killing People Around the World and It's } \\
\text { Only Going to Get Worse }\end{array}$ & The Guardian \\
\hline 95 & $\begin{array}{l}\text { This has to be the year the world agrees on climate change, } \\
\text { says Obama in Alaska }\end{array}$ & The Guardian \\
\hline 96 & $\begin{array}{l}\text { Climate Change, Chaos, and The Little Ice Age - Crash } \\
\text { Course World History } 206\end{array}$ & Crash Course \\
\hline 97 & Cambio climático: el gigante Tetris terrestre - Joss Fong & TED \\
\hline 98 & Debate over climate change gets heated & Fox News \\
\hline 99 & No climate change impact on insurance biz: Buffett & CNBC \\
\hline 100 & Investing in climate change: A 25-stock index - CNBC.com & CNBC \\
\hline 101 & Climate Change Denier - YouTube & Pig With The Face of a Boy \\
\hline 102 & Climate Change Is Happening Faster Than You Think & Dnews \\
\hline 103 & $\begin{array}{l}\text { Shell is asking us to bet against the world on climate change, } \\
\text { says leading economist }\end{array}$ & The Guardian \\
\hline
\end{tabular}




\begin{tabular}{|c|c|c|}
\hline & Title & Linked page \\
\hline 104 & Climate Change Gets Its Due In The Democratic Debate & CNN \\
\hline 105 & Climate change protesters march in New York & The Guardian \\
\hline 106 & Climate Change Basics - YouTube & $\begin{array}{l}\text { U.S. Environmental Protection } \\
\text { Agency }\end{array}$ \\
\hline 107 & $\begin{array}{l}\text { Obama defends Arctic drilling decision on eve of Alaska cli- } \\
\text { mate change trip }\end{array}$ & The Guardian \\
\hline 108 & $\begin{array}{l}\text { WHAT CLIMATE CHANGE SOUNDS LIKE FROM THE } \\
\text { AMAZON TO THE ARCTIC }\end{array}$ & $\begin{array}{l}\text { University of Minnesota y En- } \\
\text { sia }\end{array}$ \\
\hline 109 & $\begin{array}{l}\text { The Next Frontier of Climate Change: State and Local Action } \\
\text { in Virginia }\end{array}$ & New Republic \\
\hline 110 & $\begin{array}{l}\text { Obama issues challenge on climate change with power plant } \\
\text { rule }\end{array}$ & Reuters \\
\hline 111 & Why I don't care about 'Climate Change' & TEDx Teen \\
\hline 112 & $\begin{array}{l}\text { Sarah Palin Compares Climate Change 'Hysteria' To Eugen- } \\
\text { ics }\end{array}$ & Sarah Palin Channel (.com) \\
\hline 113 & Rachel Pike: The science behind a climate headline & TED \\
\hline 114 & Will American Catholics Join the Pope on Climate Change? & NBC News \\
\hline 115 & Turn Down the Heat: From Climate Science to Action & World Bank Group \\
\hline 116 & When climate change wipes your country off the map & CNN \\
\hline 117 & $\begin{array}{l}\text { We're } \mathrm{f}^{* * * * * \prime} \text { : Climate change will be catastrophic for man- } \\
\text { kind after study reveals methane leaking from the Arctic } \\
\text { Ocean, scientist warns }\end{array}$ & Dr. Jason Box \\
\hline 118 & $\begin{array}{l}\text { Obama to unveil unprecedented climate change plans to } \\
\text { slash fossil fuel emissions }\end{array}$ & Daily Mail / The White House \\
\hline 119 & $\begin{array}{l}\text { US climate change deniers lambast the Pope over his envir- } \\
\text { onment encyclical }\end{array}$ & The Guardian \\
\hline 120 & $\begin{array}{l}\text { So much for clearing up the planet! Climate change protesters } \\
\text { who marched through Manhattan are branded hypocrites for } \\
\text { leaving litter strewn across the city }\end{array}$ & Daily Mail \\
\hline 121 & Ministry of Environment, Energy and Climate Change & $\begin{array}{l}\text { Ministry of Environment, En- } \\
\text { ergy and Climate Change }\end{array}$ \\
\hline 122 & $\begin{array}{l}\text { Climate change tragedy on horizon, ex-Bank governor Mark } \\
\text { Carney says }\end{array}$ & The Star \\
\hline 123 & Inside the Senate's big vote on whether climate change is real & The Hill \\
\hline 124 & $\begin{array}{l}\text { Ted Cruz tells Nasa to stick to space and stay out of climate } \\
\text { change }\end{array}$ & The Guardian \\
\hline 125 & Connecting climate change and economic recovery & McKinsey \& Company \\
\hline 126 & CityTalks 2015: The Politics of Climate Change & City Talks 2015 \\
\hline 127 & Al Gore: Averting the climate crisis I TED Talk I TED.com & TED \\
\hline 128 & Nations Preparing to Deal with Climate Change & Daily News \\
\hline 129 & $\begin{array}{l}\text { CLIMATE CHANGE RAPIDLY ACCELERATING Part } 1 \text { - } \\
\text { Paul Beckwith - April } 2015\end{array}$ & ClimateChange12.com \\
\hline 130 & Monitoring Climate from Space - European Space Agency & European Space Agency \\
\hline 131 & CLIMATE CHANGE In Animation - YouTube & Green College Online \\
\hline 132 & UN Climate Change Report Delivers Stark Warnings & Huff Post \\
\hline 133 & Bill Nye On Climate Change And Solution - Business Insider & Business Insider \\
\hline 134 & Ocean Temperature and Acidity & US EPA \\
\hline 135 & $\begin{array}{l}\text { Save the world before it's too late:' Robert Redford ad- } \\
\text { dresses UN urging leaders to take immediate action on cli- } \\
\text { mate change }\end{array}$ & Daily Mail \\
\hline 136 & Exxon Researched Climate Change in 1977 I FRONTLINE & Frontline \\
\hline 137 & Climate change bargains: the hottest deals of 2056 & UCB Comedy \\
\hline 138 & Pope calls for action on climate change at White House & The Guardian \\
\hline 139 & $\begin{array}{l}\text { Bill Nye explains climate change in } 90 \text { seconds using only } \\
\text { emoji }\end{array}$ & EmojiScience.com \\
\hline
\end{tabular}




\begin{tabular}{|c|c|c|}
\hline & Title & Linked page \\
\hline 140 & $\begin{array}{l}\text { NDP proposes national cap-and-trade system to fight climate } \\
\text { change }\end{array}$ & The Star \\
\hline 141 & $\begin{array}{l}\text { The evidence is overwhelming' David Attenborough hits out } \\
\text { at climate change deniers }\end{array}$ & Sky News HD \\
\hline 142 & $\begin{array}{l}\text { No one will be untouched': Climate change will lead to war, } \\
\text { famine and extreme weather, claims IPCC report }\end{array}$ & WPTV \\
\hline 143 & Bjorn Lomborg: Bjorn Lomborg define prioridades globales & TED \\
\hline 144 & $\begin{array}{l}\text { Climate Change Could Cost The World Trillions More Than } \\
\text { We Thought }\end{array}$ & AP (Agencia) / NASA \\
\hline 145 & Will companies solve climate change before countries? & CNBC \\
\hline 146 & $\begin{array}{l}\text { Pope's bombshell climate change views could be a 'game- } \\
\text { changer' }\end{array}$ & AP (Agencia) \\
\hline 147 & Pope releases major climate change doctrine - Yahoo News & Yahoo News \\
\hline 148 & $\begin{array}{l}\text { Cargill media statement on Risky Business Climate Change } \\
\text { Report }\end{array}$ & Risky Business / Cargill \\
\hline 149 & Game of Thrones is secretly all about climate change & Vox \\
\hline 150 & We have to challenge the pervasive silence on climate change' & The Guardian \\
\hline 151 & $\begin{array}{l}\text { Obama pushes climate change action on Earth Day: 'Folks } \\
\text { don't have time' to wait }\end{array}$ & $\begin{array}{l}\text { The Guardian / The White } \\
\text { House }\end{array}$ \\
\hline 152 & What is Climate Change? - YouTube & $\begin{array}{l}\text { Australia Government, Great } \\
\text { Barrier Reef Marine Park Au- } \\
\text { thority }\end{array}$ \\
\hline 153 & Bill Nye Debates Climate Change With Economist - CNN 5 & $\mathrm{CNN}$ \\
\hline 154 & Peer pressure' to steer climate change I Reuters.com & Reuters \\
\hline 155 & Science for a Hungry World: Agriculture and Climate Change & Nasa \\
\hline 156 & $\begin{array}{l}\text { Obama Admin Builds Economic Case For Action On Climate } \\
\text { Change, As House Preps To Block It }\end{array}$ & AP (Agencia) \\
\hline 157 & Will Filipinos have to abandon Manila to climate change? & The Guardian \\
\hline 158 & $\begin{array}{l}\text { Ben Carson Has No Idea What Climate Change Is, But Says } \\
\text { We Should Protect The Planet }\end{array}$ & Huff Post \\
\hline 159 & $\begin{array}{l}\text { Green billionaire's '16 gameplan? Shame GOP on climate } \\
\text { change }\end{array}$ & The Hill \\
\hline 160 & $\begin{array}{l}\text { Fox News Host: Climate Change Hoax Costs Us Our Free- } \\
\text { dom! }\end{array}$ & The Young Turks \\
\hline 161 & $\begin{array}{l}\text { Delaying action on climate change puts Canadian economy } \\
\text { at risk: report }\end{array}$ & The Globe and Mail \\
\hline 162 & $\begin{array}{l}\text { President Obama Rolls the Dice in Las Vegas on Climate } \\
\text { Change }\end{array}$ & NBC News \\
\hline 163 & $\begin{array}{l}\text { Charlotte Church says climate change helped cause Syrian } \\
\text { conflict }\end{array}$ & The Telegraph \\
\hline 164 & Pope Francis at center of climate change debate & Fox News \\
\hline 165 & $\begin{array}{l}\text { Barack Obama interviews David Attenborough on climate } \\
\text { change }\end{array}$ & $\mathrm{BBC}$ \\
\hline 166 & Climate change can no longer be denied - Daily Mail & Reuters \\
\hline 167 & How could climate change affect people worldwide? & Science Museum \\
\hline 168 & $\begin{array}{l}\text { Pope Francis Calls On Congress To Take 'Courageous Ac- } \\
\text { tions' On Climate Change }\end{array}$ & $\mathrm{CNN}$ \\
\hline 169 & Can the Republicans halt climate change? & the guardian \\
\hline 170 & Changing Weather and Climate in the Great Lakes Region & coursera \\
\hline 171 & $\begin{array}{l}\text { Cyclone Pam: } 24 \text { confirmed dead as Vanuatu president } \\
\text { blames climate change }\end{array}$ & the guardian \\
\hline 172 & Martin O'Malley: Climate Change Created ISIS & Real Clear Politics \\
\hline 173 & $\begin{array}{l}\text { How to Win Climate Change Debate Every Time (Global } \\
\text { Warming Hoax) }\end{array}$ & Redsilverj \\
\hline 174 & The History of Climate Change Negotiations in 83 seconds & CICERO \\
\hline
\end{tabular}




\begin{tabular}{|c|c|c|}
\hline & Title & Linked page \\
\hline 175 & "We can't wait": Combating the effects of climate change & CBS News \\
\hline 176 & Global Climate Change: Effects and Mitigation Strategies & Study.com \\
\hline 177 & $\begin{array}{l}\text { Scientists to Americans: We're Not Divided on Climate } \\
\text { Change }\end{array}$ & $\begin{array}{l}\text { The American Association for } \\
\text { the Advancement of Science } \\
\text { (AAAS) }\end{array}$ \\
\hline 178 & $\begin{array}{l}\text { US, China Face Distinct Challenges on Climate Change - } \\
\text { VOA }\end{array}$ & VOA News \\
\hline 179 & UN Said to Summon Leaders to Closed-Door Climate Change & Bloomberg Business \\
\hline 180 & $\begin{array}{l}\text { Republican Calls Climate Change A Hoax Because Earth And } \\
\text { Mars Have 'Exactly' Same Temperature }\end{array}$ & Huff Post \\
\hline 181 & 11/15/14 Climate Change - YouTube & Lewis Black \\
\hline 182 & $\begin{array}{l}\text { In Alaska, Obama Highlights Climate Change While His De- } \\
\text { cisions Draw Accusations Of 'Hypocrisy' }\end{array}$ & Huff Post \\
\hline 183 & Climate Change - the scientific debate & potholer54 \\
\hline 184 & Climate change - YouTube & climatechallange.gov.uk \\
\hline 185 & $\begin{array}{l}\text { Have three climate change scientists been ASSASSINATED? } \\
\text { The astonishing claim made by a Cambridge professor }\end{array}$ & ENVISIONATION \\
\hline 186 & Climate Change and the Global Ocean & NASA \\
\hline 187 & Obama on impact of climate change on his family's health & CBS News \\
\hline 188 & Finally, a climate change game you'd actually want to play & EARTH A PRIMER \\
\hline 189 & Top 6 Climate Change Problems & Apoorv Tiwary \\
\hline 190 & How does climate change affect biodiversity? - YouTube & $\begin{array}{l}\text { California Academy of Sci- } \\
\text { ences }\end{array}$ \\
\hline 191 & $\begin{array}{l}\text { One Direction accused of having two faces as they back cli- } \\
\text { mate change campaign despite 'often' using TWO private jets }\end{array}$ & action/1D \\
\hline 192 & Neil deGrasse Tyson on Climate Change - YouTube & StarTalkRadio \\
\hline 193 & $\begin{array}{l}\text { Barack Obama: climate change can no longer be denied or } \\
\text { ignored }\end{array}$ & reuters \\
\hline 194 & $\begin{array}{l}\text { Rick Santorum Tries To Explain Why He Can Weigh In On } \\
\text { Climate Change But Pope Shouldn't }\end{array}$ & Fox News \\
\hline 195 & $\begin{array}{l}\text { Marco Rubio Says He's Fine With The Pope's Climate Change } \\
\text { Positioning }\end{array}$ & Huff Post \\
\hline 196 & $\begin{array}{l}5 \text { THINGS YOU NEED TO KNOW ABOUT CLIMATE } \\
\text { CHANGE }\end{array}$ & National Geographic Channel \\
\hline 197 & $\begin{array}{l}\text { California governor criticizes Tories over climate change } \\
\text { policies at summit }\end{array}$ & The Canadian Press \\
\hline 198 & $\begin{array}{l}\text { Bernie Sanders: Republicans are an "embarrassment" on cli- } \\
\text { mate change }\end{array}$ & Vox \\
\hline 199 & $\begin{array}{l}\text { Dutch Citizens Are Taking Their Government To Court Over } \\
\text { Climate Change }\end{array}$ & Huff Post \\
\hline 200 & In Greenland, climate change is already hard at work & CBS News \\
\hline 201 & How to cash in on climate change - CNBC.com & CNBC \\
\hline 202 & Climate Scientist Schools Climate Change Denying Senator & TDC \\
\hline 203 & $\begin{array}{l}\text { Global Warming: A Way Forward: Facing Climate Change - } \\
\text { NationalGeographic.com - 24hToday.com }\end{array}$ & National Geographic \\
\hline 204 & What if climate change is real? I Katharine Hayhoe - YouTube & TED \\
\hline 205 & These New Orleans musicians have the climate change blues & the guardian \\
\hline 206 & Senator Who Cited Snowball In Climate Change Debate Cites & Huff Post \\
\hline 207 & How do scientists predict future climate change? & Science Museum \\
\hline 208 & $\begin{array}{l}2014 \text { proves hottest on record, driven in part by climate } \\
\text { change }\end{array}$ & CBS News \\
\hline 209 & Pikas and Climate Change ISmithsonian & assignment earth \\
\hline 210 & Obama tells Coast Guard grads climate change threatens U.S & Reuters \\
\hline 211 & President Obama: Climate change hurts national security & MSNBC \\
\hline 212 & President on Actions Against Climate Change - YouTube & The New York Times \\
\hline
\end{tabular}




\begin{tabular}{|c|c|c|}
\hline & Title & Linked page \\
\hline 213 & $\begin{array}{l}\text { Obama At U.S. Coast Guard Academy Commencement: } \\
\text { Denying Climate Change "Dereliction Of Duty" }\end{array}$ & Real Clear Politics \\
\hline 214 & Don't say "climate change" in Florida - YouTube & Fox 13 News - Tampa Bay \\
\hline 215 & Energy Union - European Commission & European Commission \\
\hline 216 & $\begin{array}{l}\text { Helen Clark welcomes Pope Francis' climate change encyc- } \\
\text { lical }\end{array}$ & UNDP \\
\hline 217 & Climate change and resource scarcity - PwC & PwC U.K. \\
\hline 218 & $\begin{array}{l}\text { Region grapples with hotter future as it looks to adapt to cli- } \\
\text { mate change }\end{array}$ & STLtoday \\
\hline 219 & How is Wisconsin's climate changing? & WICCI \\
\hline 220 & Hillary Clinton Goes After GOP Climate Change Deniers & ABC News \\
\hline 221 & Florida worker sent home for sharing climate change views? & MSNBC \\
\hline 222 & $\begin{array}{l}\text { Piccadilly Pond and paddy fields outside Parliament: Artists } \\
\text { imagine London in } 2100 \text { after climate change has taken its toll }\end{array}$ & $\begin{array}{l}\text { World Meteorological Organ- } \\
\text { ization }\end{array}$ \\
\hline 223 & Climatoon: An Animated Climate Change Chat & Time Magazine \\
\hline 224 & $\begin{array}{l}27 \text { - The evidence for climate change WITHOUT computer } \\
\text { models or the IPCC }\end{array}$ & potholer54 \\
\hline 225 & $\begin{array}{l}\text { Peter Dutton caught joking about climate change with Tony } \\
\text { Abbott }\end{array}$ & David Smith \\
\hline 226 & $\begin{array}{l}\text { Our scorched Earth in 2100: Nasa maps reveal how climate } \\
\text { change will cause temperatures to soar }\end{array}$ & Mail Online \\
\hline 227 & $\begin{array}{l}\text { Climate change could cause the Antarctic ice shelf to collapse } \\
\text { by } 2100, \text { study claims }\end{array}$ & WH.GOV \\
\hline 228 & $\begin{array}{l}\text { Earnest: Congress Shouldn't Have A Role In Climate Change } \\
\text { Agreement Because They Don't Acknowledge It Exists }\end{array}$ & Real Clear Politics \\
\hline 229 & $\begin{array}{l}\text { Extreme Weather Tied to Climate Change, Not Recent US } \\
\text { Snow Event }\end{array}$ & VOA News \\
\hline 230 & Climate Change in a Bottle: The Lesson Part 2 of 4 & Teaching Channel \\
\hline 231 & $\begin{array}{l}\text { ‘WE'RE GOING TO DO WHATEVER WE WANT' IMMIG- } \\
\text { RATION ENFORCERS UNLEASHED BY TRUMP }\end{array}$ & Huff Post \\
\hline 232 & Future Climate Change, Establishing a Target Temperature & Climate Communication \\
\hline 233 & $\begin{array}{l}\text { Scott Brown, Cory Gardner Shift Stance On Climate Change } \\
\text { In First Senate Debates }\end{array}$ & Huff Post \\
\hline 234 & $\begin{array}{l}\text { Q\&A: Naomi Klein goes head to head with Australian writer } \\
\text { Tom Switzer on climate change }\end{array}$ & the guardian \\
\hline 235 & $\begin{array}{l}\text { UN Scientific Panel Releases Report Sounding Alarm On Cli- } \\
\text { mate Change }\end{array}$ & Huff Post \\
\hline 236 & $\begin{array}{l}\text { Neil deGrasse Tyson: Don't Worry, Earth Will Survive Cli- } \\
\text { mate Change - We Won't }\end{array}$ & Business Insider \\
\hline 237 & $\begin{array}{l}\text { Bill Nye's 'Twin Brother' Reveals the Truth About Climate } \\
\text { Change and Fossil Fuels }\end{array}$ & EcoWatch \\
\hline 238 & What's the evidence humans are causing climate change? & Science Museum \\
\hline 239 & Atmosphere: exploring climate science - - Science Museum & Science Museum \\
\hline 240 & Climate debate turns nasty & Atlantic Council \\
\hline 241 & Erratic Weather or Climate Change? - at The Real News & the Real News \\
\hline 242 & $\begin{array}{l}\text { Science is telling us that time is running out': UN climate } \\
\text { chief warns the world is 'playing with fire' unless agreement } \\
\text { on climate change is reached at international summit }\end{array}$ & Mail Online \\
\hline 243 & $\begin{array}{l}\text { Al Gore says climate change fight will spur global economic } \\
\text { growth }\end{array}$ & The Globe and Mail \\
\hline 244 & The Most Terrifying Video You'll Ever See - YouTube & wonderingmind 42 \\
\hline 245 & Ep. 301 Clip: Climate Change Deniers IVICE on HBO & $\mathrm{HBO}$ \\
\hline 246 & $\begin{array}{l}\text { Climate Change Denial Is Real \& Man-made, Here's Undeni- } \\
\text { able Proof }\end{array}$ & The Young Turks \\
\hline 247 & Climate Change I David Mitchell's SoapBox UPDATE & David Mitchell's Soapbox \\
\hline
\end{tabular}




\begin{tabular}{|c|c|c|}
\hline & Title & Linked page \\
\hline 248 & Obama: Climate Change Is Harming Americans' Health & Huff Post \\
\hline 249 & $\begin{array}{l}\text { Watch Bill Nye Debate Republican Congresswoman On Cli- } \\
\text { mate Change }\end{array}$ & NBCnews \\
\hline 250 & $\begin{array}{l}\text { Climate Change Is The Single Most Divisive Political Issue, } \\
\text { Says Poll }\end{array}$ & Huff Post \\
\hline 251 & An Islander's Bid to Be the World's First Climate Refugee & Bloomberg Business \\
\hline 252 & $\begin{array}{l}\text { Dire UN report warns climate change a threat to human se- } \\
\text { curity }\end{array}$ & The Globe and Mail \\
\hline 253 & Our Year of Extremes: Did Climate Change Just Hit Home? & NBC News \\
\hline 254 & How do you solve a problem like the climate crisis? & TED \\
\hline 255 & $\begin{array}{l}\text { Climate change already impacting food supplies, says UN re- } \\
\text { port }\end{array}$ & CBS News \\
\hline 256 & Climate Change 2014: Impacts, Adaptation and Vulnerability & IPCC \\
\hline 257 & Al Gore: What comes after An Inconvenient Truth? & TED \\
\hline 258 & The Louisiana Town Devoured by Climate Change & The Atlantic \\
\hline 259 & $\begin{array}{l}\text { Fox News Host to Santorum: If Only Scientists Can Talk Cli- } \\
\text { mate Change, Shouldn't You Shut Up? }\end{array}$ & Fox News \\
\hline 260 & Armstrong \& Miller - Climate Change & lifestudios \\
\hline 261 & Climate Change and the Colorado River & assignment earth \\
\hline 262 & Finally, 'Cosmos' Takes On Climate Change & Huff Post \\
\hline 263 & Naomi Klein on climate change and austerity & the guardian \\
\hline 264 & $\begin{array}{l}\text { Climate Change: Our greatest health threat, or our greatest } \\
\text { opportunity for better health? }\end{array}$ & $\begin{array}{l}\text { Global Climate and Health Al- } \\
\text { liance }\end{array}$ \\
\hline 265 & Best Climate Change Advert - YouTube & ACT ON CO2 \\
\hline 266 & Climate Change: State of the Earth - National Geographic & National Geographic Channel \\
\hline 267 & $\begin{array}{l}\text { Climate Change: Our greatest health threat, or our greatest } \\
\text { opportunity for better health? }\end{array}$ & Mail Online \\
\hline 268 & Climate Change in a Bottle: The Set-Up Part 3 of 4 & Teaching Channel \\
\hline 269 & Historic Obama Alaska trip to focus on climate change & CBS News \\
\hline 270 & The Arctic: Our First Sign of Climate Change I Ocean Today & wwf \\
\hline 271 & $\begin{array}{l}\text { Assessing the Costs of Climate Change and Adaptation in } \\
\text { South Asia }\end{array}$ & Asian Development Bank \\
\hline 272 & White Man Behind A Desk: Climate Change - YouTube & White Man Behind A Desk \\
\hline 273 & Adapting to Climate Change in Europe and Central Asia & World Bank Group \\
\hline 274 & $\begin{array}{l}\text { Pope Francis: Why Congress needs to do something about } \\
\text { climate change }\end{array}$ & Mashable \\
\hline 275 & $\begin{array}{l}\text { Xiuhtezcatl, Indigenous Climate Activist at the High-level } \\
\text { event on Climate Change }\end{array}$ & United Nation \\
\hline 276 & Fiorina: Innovation is only answer to climate change & CNBC \\
\hline 277 & Barack Obama unveils tougher climate change plan & the guardian \\
\hline 278 & $\begin{array}{l}\text { Symphony of Science - Our Biggest Challenge (Climate } \\
\text { Change Music Video) }\end{array}$ & melodysheep \\
\hline 279 & $\begin{array}{l}\text { Obama administration recasts climate change as a national } \\
\text { security issue }\end{array}$ & Mashable \\
\hline 280 & Climate change, a factor in Texas floods, largely ignored & KXAN \\
\hline 281 & Learn English 34 - Climate Change - YouTube & EF podEnglish - Learn English \\
\hline 282 & Pope Francis Calls for Action on Climate Change - NBC News & NBC News \\
\hline 283 & $\begin{array}{l}\text { The impact of climate change on some of the best-known } \\
\text { wine areas }\end{array}$ & Al Jazeera America \\
\hline 284 & $\begin{array}{l}\text { Cloudy climate change: How clouds affect Earth's ...- You- } \\
\text { Tube }\end{array}$ & TED-Ed \\
\hline 285 & $\begin{array}{l}\text { 15-Year-Old Climate Activist Speaks To UN General As- } \\
\text { sembly }\end{array}$ & Huff Post \\
\hline 286 & Paris Rolls Out Blueprint to Fight Climate Change - VOA & VOA News \\
\hline 287 & U.S., China Unveil Ambitious Climate Change Goals & Huff Post \\
\hline
\end{tabular}

Continued on the next page 


\begin{tabular}{|l|l|l|}
\hline & Title & Linked page \\
\hline 288 & Obama on Putin aggression: Climate change more important & 60 minutes \\
\hline 289 & Time and Space & Google \\
\hline 290 & $\begin{array}{l}\text { Climate scientists criticize government paper that erases } \\
\text { 'pause' in warming }\end{array}$ & Fox News \\
\hline 291 & $\begin{array}{l}\text { Dem Debate: Inequality, Climate Change, Marijuana, Reli- } \\
\text { gion }\end{array}$ & David Pakman Show \\
\hline 292 & Imaginary Lines - Papal Encyclical on Climate Change & teleSUR \\
\hline 293 & Latin America A World Leader in Attacking Climate Change & teleSUR \\
\hline 294 & Climate change: Asia & EDA \\
\hline 295 & The new leader of the climate change fight I MSNBC & MSNBC \\
\hline 296 & Can We Fix Climate Change? - National Geographic Channel & National Geographic Channel \\
\hline 297 & Climate change: Africa (de) & EDA \\
\hline 298 & U.S.A.: Obama Takes Major Step to Combat Climate Change & teleSUR \\
\hline 299 & Imaginary Lines - Papal Encyclical on Climate Change & teleSUR \\
\hline 300 & $\begin{array}{l}\text { Symposium Overview - Climate Change: Generating Busi- } \\
\text { ness and Organisational Responses }\end{array}$ & The University of Sydney \\
\hline
\end{tabular}

\section{References}

Allan, S., Adam, B. and Carter, C. (2000). Environmental risks and the media. London, U.K.: Routledge.

Allgaier, J. (2013). 'On the Shoulders of YouTube: Science in Music Videos'. Science Communication 35 (2), pp. 266-275. DOI: 10.1177/1075547012454949.

Alvarado, M., Buonanno, M., Gray, H. and Miller, T., eds. (2014). The SAGE Handbook of Television Studies. California, U.S.A.: Sage.

Aufderheide, P. (1986). 'Music Videos: The Look of the Sound'. Journal of Communication 36 (1), pp. 57-78. DOI: 10.1111/j.1460-2466.1986.tb03039.x.

Benevenuto, F., Rodrigues, T., Almeida, V., Almeida, J. and Ross, K. (2009). 'Video interactions in online video social networks'. ACM Transactions on Multimedia Computing, Communications, and Applications 5 (4), pp. 1-25. DOI: $10.1145 / 1596990.1596994$.

Boykoff, M. T. (2008). 'Media and scientific communication: a case of climate change'. Geological Society, London, Special Publications 305 (1), pp. 11-18. DOI: 10.1144/SP305.3.

Brewer, P. R. and McKnight, J. (2015). 'Climate as Comedy: The Effects of Satirical Television News on Climate Change Perceptions'. Science Communication 37 (5), pp. 635-657. DOI: 10.1177/1075547015597911.

Brown Jarreau, P. (2015). 'Science bloggers' self-perceived communication roles'. JCOM 14 (4), A02.

URL: https://jcom.sissa.it/archive/14/04/JCOM_1404_2015_A02.

Burgess, J. and Green, J. (2013). YouTube: Online video and participatory culture. John Wiley \& Sons.

Cisco (1st June 2016). Cisco White paper: Cisco VNI Forecast and Methodology, 2015-2020. URL: http://www.cisco.com/c/en/us/solutions/collateral/serv ice-provider/visual-networking-index-vni/complete-white-paper-c11-4 $81360 . \mathrm{html}$.

De Lara, A. (2014). 'Searching for quality: a debate among journalists, scientists and readers about the coverage of climate change in the Spanish media'. Revista Prisma Social 12, pp. 196-231.

Dunwoody, S. (2008). 'Science journalism'. In: Handbook of Public Communication of Science and Technology. Ed. by M. Bucchi and B. Trench. London, U.K. and New York, U.S.A.: Routledge, pp. 15-26. 
Erviti, M. C. and Stengler, E. (2016). 'Online science videos: an exploratory study with major professional content providers in the United Kingdom'. JCOM 15 (6), A06. URL: https://jcom.sissa.it/archive/15/06/JCOM_1506_2016_A06.

Favero, P. (2014). 'Learning to look beyond the frame: reflections on the changing meaning of images in the age of digital media practices'. Visual Studies 29 (2), pp. 166-179. DOI: 10.1080/1472586X.2014.887269.

García-Avilés, J. A. (2012). 'Roles of audience participation in multiplatform television: From fans and consumers, to collaborators and activists'. Participations. Journal of Audience and Reception Studies 9 (2), pp. 429-447.

Geisler, G. and Burns, S. (2007). 'Tagging video: conventions and strategies of the YouTube community'. In: Proceedings of the 7th ACM/IEEE-CS joint conference on Digital libraries. ACM Press, p. 480. DOI: 10.1145/1255175.1255279.

Gifreu, A. (2011). 'The interactive multimedia documentary as a discourse on interactive non-fiction: for a proposal of the definition and categorisation of the emerging genre'. Hipertext.net 9. URL: http://www . upf . edu/hipertextnet/en/n umero-9/interactive-multimedia.html.

Greenberg, M. R., Sachsman, D. B., Sandman, P. M. and Salomone, K. L. (1989). 'Network Evening News Coverage of Environmental Risk'. Risk Analysis 9 (1), pp. 119-126. DOI: 10.1111/j.1539-6924.1989.tb01227.x.

Hansen, A. (1993The Mass Media and Environmental Issues). Leicester, U.K.: Leicester University Press.

Hart, P. S. and Feldman, L. (2014). 'Threat Without Efficacy? Climate Change on U.S. Network News'. Science Communication 36 (3), pp. 325-351. DOI: $10.1177 / 1075547013520239$.

Hulme, M. (2007). Mediating the messages about climate change: reporting the IPCC Fourth Assessment in the U.K. print media. Ed. by T. Boyce and J. Lewis. New York, U.S.A.: Peter Lang, pp. 117-131.

Jeffs, T. and Smith, M., eds. (1990). Using informal education. Buckingham, U.K.: Open University Press.

Kim, J. (2012). 'The institutionalization of YouTube: From user-generated content to professionally generated content'. Media, Culture $\mathcal{E}$ Society 34 (1), pp. 53-67. DOI: $10.1177 / 0163443711427199$.

Kousha, K., Thelwall, M. and Abdoli, M. (2012). 'The role of online videos in research communication: A content analysis of YouTube videos cited in academic publications'. Journal of the American Society for Information Science and Technology 63 (9), pp. 1710-1727. DOI: 10.1002/asi.22717.

Krutnik, F. and Neale, S. (2006). Popular film and television comedy. New York, U.S.A.: Routledge.

León, B. and Erviti, M. C. (2011). 'Portrayal of scientific controversy on climate change. A study of the coverage of the Copenhagen summit in the Spanish press'. Observatorio (OBS*) 5 (3). DOI: $10.7458 /$ obs532011503.

- (2015). 'Science in pictures: Visual representation of climate change in Spain's television news'. Public Understanding of Science 24 (2), pp. 183-199. DOI: $10.1177 / 0963662513500196$.

Livingstone, S. and Lunt, P. (2002). Talk on television: Audience participation and public debate. London, U.K.: Routledge.

Lopera, E. and Moreno, C. (2015). 'The uncertainties of climate change in Spanish daily newspapers: content analysis of press coverage from 2000 to $2010^{\prime}$. JCOM 13 (1), A02.

URL: https://jcom.sissa.it/archive/13/01/JCOM_1301_2014_A02. 
Lorenzoni, I. and Pidgeon, N. F. (2006). ‘Public Views on Climate Change: European and USA Perspectives'. Climatic Change 77 (1), pp. 73-95. DOI: $10.1007 / \mathrm{s} 10584-006-9072-z$.

Meira, P. A., Arto, M., Heras, F., L., I., Lorenzo, J. J. and Montero, P. (2013). La respuesta de la sociedad española ante el cambio climático. Madrid, Spain: Fundación Mapfre.

Morton, T. A., Rabinovich, A., Marshall, D. and Bretschneider, P. (2011). 'The future that may (or may not) come: How framing changes responses to uncertainty in climate change communications'. Global Environmental Change 21 (1), pp. 103-109. DOI: 10.1016/j.gloenvcha.2010.09.013.

Muñoz Morcillo, J., Czurda, K. and Robertson-von Trotha, C. Y. (2016). ‘Typologies of the popular science web video'. JCOM 15 (04), A02. URL: https://jcom.sissa.it/archive/15/04/JCOM_1504_2016_A02.

Nash, K. (2012). 'Modes of interactivity: analysing the webdoc'. Media, Culture $\mathcal{E}$ Society 34 (2), pp. 195-210. DOI: 10.1177/0163443711430758.

Nichols, B. (1991). Representing reality: Issues and concepts in documentary. Vol. 681. Indiana, U.S.A.: Indiana University Press.

Painter, J. (2013). Climate change in the media: Reporting risk and uncertainty. London, U.K.: IB Tauris.

Peer, L. and Ksiazek, T. B. (February 2011). 'YouTube and the challenge to journalism: new standards for news videos online'. Journalism Studies 121, pp. 45-63. DOI: 10.1080/1461670X.2010.511951.

Pinto, B., Marçal, D. and Vaz, S. G. (2015). 'Communicating through humour: a project of stand-up comedy about science'. Public Understanding of Science 24 (7), pp. 776-793. DOI: $10.1177 / 0963662513511175$.

Roth, W.-M. and Friesen, N. (2014). 'Nacherzeugung, Nachverstehen: A phenomenological perspective on how public understanding of science changes by engaging with online media'. Public Understanding of Science 23 (7), pp. 850-865. DOI: 10.1177/0963662513512441.

Saló, G. (2003). ¿Qué es eso del formato? Cómo nace y se desarrolla un programa de televisión. Barcelona, Spain: Gedisa.

Smith, J. (2005). ‘Dangerous News: Media Decision Making about Climate Change Risk: Media Decision Making about Climate Change Risk'. Risk Analysis 25 (6), pp. 1471-1482. DOI: 10.1111/j.1539-6924.2005.00693.x.

Soulages, J.-C. (2007). Les rhétoriques télévisuelles. Le formatage du regard. Brussels, Belgium: De Boeck-INA.

Statista (2016). Statistics and facts about online video usage. URL: http://www. statista.com/topics/1137/onlinevideo/.

Sterman, J. D. (2008). 'Risk Communication on Climate: Mental Models and Mass Balance'. Science 322 (5901), pp. 532-533. DOI: 10.1126/science. 1162574.

Sugimoto, C. R. and Thelwall, M. (2013). 'Scholars on soap boxes: Science communication and dissemination in TED videos'. Journal of the American Society for Information Science and Technology 64 (4), pp. 663-674. DOI: 10.1002 /asi. 22764.

Tan, A.-L., Jocz, J. A. and Zhai, J. (2015). 'Spiderman and science: How students' perceptions of scientists are shaped by popular media'. Public Understanding of Science, p. 096366251561508. DOI: 10.1177/0963662515615086.

Teixeira, T. S. (2012). 'The New Science of Viral Ads'. Harvard Business Review 49, pp. 25-27. 
Thelwall, M., Sud, P. and Vis, F. (2012). 'Commenting on YouTube videos: From guatemalan rock to El Big Bang'. Journal of the American Society for Information Science and Technology 63 (3), pp. 616-629. DOI: 10.1002/asi. 21679.

van Dijck, J. (2009). 'Users like you? Theorizing agency in user-generated content'. Media, Culture \& Society 31 (1), pp. 41-58. DOI: 10.1177/0163443708098245.

- (2013). The Culture of Connectivity. A Critical History of Social Media. New York, U.S.A.: Oxford University Press.

Van Riper, A. B. (2003). 'What the public thinks it knows about science'. EMBO Reports 4 (12), pp. 1104-1107. DOI: 10.1038/sj . embor. 7400040.

Welbourne, D. J. and Grant, W. J. (2015). 'Science communication on YouTube: Factors that affect channel and video popularity'. Public Understanding of Science 25 (6), pp. 706-718. DOI: 10.1177/0963662515572068.

Wunsch-Vincent, S. and Vickery, G. (2007). Participative web: User-created content. Technical Report DSTI/ICCP/IE(2006)7/FINAL. Compiled for the Working Party on the Information Economy of the Committee for Information, Computer and Communications Policy of the OECD's Directorate for Science, Technology and Industry. Organisation for Economic Co-operation and Development.

YouTube (2016). Statistics.

URL: https://www. youtube.com/yt/press/statistics.html.

Authors

How to cite

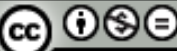

Alicia de Lara González is the Journalism Degree Coordinator of the University Miguel Hernández (Spain), where she teaches Journalistic Writing. She is editor of the popular science online magazine UMH Sapiens. In the academic field, she has been researching on science journalism and information on climate change. E-mail: a.lara@umh.es.

Jose A. García-Avilés is the head of the Journalism section of the University Miguel Hernández (Spain), where he teaches Media \& Communication. He holds a BA from the University of Ireland and a Ph.D. in Journalism from the University of Navarre. He has been researching on media convergence since 2002 and has published extensively on journalism and communication studies.

E-mail: jose.garciaa@umh.es.

Gema Revuelta is Director of the Studies Center on Science, Communication and Society from Universitat Pompeu Fabra and associated professor of Science Communication at the same university. She is co-Director of the Masters' programme on Science Communication at UPF Barcelona School of Management, together with Vladimir de Semir. She is also Director of the Quiral Report, an annual publication that analyses health and medicine information published in the most popular Spanish mass media. Gema has been involved for more than 20 years in the fields of science communication and science journalism.

E-mail: gema.revuelta@upf.edu.

De Lara, A., García Avilés, J. A. and Revuelta, G. (2017). 'Online video on climate change: a comparison between television and web formats'. JCOM 16 (01), A04.

This article is licensed under the terms of the Creative Commons Attribution - NonCommercial - NoDerivativeWorks 4.0 License. ISSN 1824-2049. Published by SISSA Medialab. jcom.sissa.it 